Georgia State University

ScholarWorks @ Georgia State University

$7-2-2008$

\title{
Labor Law and Employment Regulation: Neoclassical and Institutional Perspectives
}

Bruce E. Kaufman

Georgia State University, bkaufman@gsu.edu

Follow this and additional works at: https://scholarworks.gsu.edu/uwrg_workingpapers

\section{Recommended Citation}

Kaufman, Bruce E., "Labor Law and Employment Regulation: Neoclassical and Institutional Perspectives" (2008). UWRG Working Papers. 24.

https://scholarworks.gsu.edu/uwrg_workingpapers/24

This Article is brought to you for free and open access by the Usery Workplace Research Group at ScholarWorks @ Georgia State University. It has been accepted for inclusion in UWRG Working Papers by an authorized administrator of ScholarWorks @ Georgia State University. For more information, please contact scholarworks@gsu.edu. 
Working Paper 2008-7-2

July 2008

\section{Labor Law and Employment Regulation: Neoclassical and Institutional Perspectives}

Bruce E. Kaufman Georgia State University 


\title{
Labor Law and Employment Regulation:
}

\section{Neoclassical and Institutional Perspectives}

\author{
Bruce E. Kaufman \\ Department of Economics \\ Andrew Young School of Policy Studies \\ Georgia State University \\ Atlanta, GA 30303 \\ July 3, 2008 \\ bkaufman@gsu.edu
}

Chapter prepared for Kenneth Dau-Schmidt (ed.), Elgar Encyclopedia of Labor and

Employment Law and Economics, forthcoming (2009). 


\title{
Chapter 2: Labor Law and Employment Regulation: Neoclassical and Institutional Perspectives
}

Bruce E. Kaufman

\begin{abstract}
This paper provides an in-depth economic analysis of the pros and cons of labor law and employment regulation. Two "law and economics" movements are identified in the USA: the first is the well-known post-World War II law and economics movement centered in neoclassical economics and the University of Chicago; the second is the largely unknown and neglected pre-World II law and economics movement centered in institutional economics and the University of Wisconsin. The former mostly provides the "con" side to employment regulation, the latter mostly provides the "pro" side. The paper describes the assumptions, methods and theories of each school of thought and their implications regarding the optimal form and extent of labor law and employment regulation.
\end{abstract}

Legal regulation of the employment relationship expanded greatly over the twentieth century in all the industrializing countries of the world. A century ago in Anglo- Saxon countries the legal relationship between employer and employee was regulated by the common law doctrine of "master and servant" (Linder 1989; Deakin and Wilkinson 2005). Rights and protections afforded employees under this doctrine were few, while statute law provisions reregulating the terms and conditions of employment were relatively elementary 
in Europe and Australasia and practically non-existent in the United States (Rodgers 1998). As a practical matter, the employment relationship was largely regarded as simply another species of commercial transaction between buyer and seller and, thus, was governed by the same generic body of contract law (Epstein 1983). Not surprisingly, a separate field of labor and employment law had yet to emerge in most countries of that era (Arthurs 2002; Birk 2002; Davies and Freedland 2002).

What a difference a century makes! From then to now have been added dozens of new employment laws and regulatory agencies governing all aspects of labor and employment. The United States, for example, did not have so much as a federal child labor law until 1938; six decades later the Dunlop Commission spoke of "an explosion in the breadth and depth of legal regulation of the American workplace," including twenty-six major statutes, one executive order, and thousands of detailed regulations (Commission of the Future of Worker-Management Relations 1994, p. 125). Employment regulation has also grown apace in other countries and, indeed, in many nations of the European Union and Latin America employment regulation considerably exceeds the US level (Blanpain 1999; Cook 2006). Accompanying the growth of employment regulation has been a similar emergence and growth of the subfield of labor and employment law both in law school curricula and the world of legal practice. Today in the US almost 30,000 attorneys list their area of specialization as labor and employment (Martindale.com); the case law in labor and employment is huge in breadth and depth (Summers, Dau-Schmidt and Hyde 2007); and the field is served by a number of well-known law reviews and journals.

A century ago many economists and legal scholars -- representing in the US what Hovenkamp (1990) calls the "first great law and economics movement" -- argued that the 
nation would benefit from greater legal regulation of the employment relationship. They also carried their argument into the global arena and made the case for a much expanded regime of international labor law, such as was initiated when the International Labor Organization (ILO) was created in 1919 (Valticos 1969; Kaufman 2004a). These proponents of employment regulation, associated with the Progressive Movement and typically drawn from the schools of institutional economics and legal realism, faced entrenched intellectual and legal opposition and political roadblocks, yet eventually carried the day, starting with the New Deal in the 1930s and moving forward in recurring periods of policy activism up to the 1980s. This law and economics movement gave rise to a public interest rationale for regulation of the employment relationship that continues to provide a large part of the theoretical and ethical core for what may be described as the "traditional" approach to labor and employment law. This approach is associated with well-known names in the post-World War II fields of labor law and industrial relations in the USA and abroad. Early examples include Benjamin Aaron, Marco Biagi, Archibald Cox, John Dunlop, Paul Durand, Otto Kahn-Freund and Clyde Summers; well recognized names in the contemporary period include Harry Arthurs, Janice Bellace, Roger Blanpain, Samuel Estreicher, Mathew Finkin, Bob Hepple, Paul Weiler and Manfred Weiss. The modern-day adherents of the first law and economics movement also have many points in common with the new program of behavioral law and economics (Sunstein 2000), as well as critical legal studies (e.g., Stone 2004).

Since the early 1980s the pendulum appears to have noticeably swung in a different and largely opposite direction on both sides of the Atlantic, although with greater receptivity and implementation in the Anglo-Saxon economies (Bernstein 2001; Yergin and 
Stanislav 2002). Over the last three decades an increasingly large and influential group of economists and legal scholars, typically affiliated with what Hovenkamp calls the "second great law and economics movement," has made a persuasive case for substantial labor market de-regulation - even to the point of returning to the common law regime that existed a century ago (e.g., Epstein 1984). The core group among these scholars are American and draw inspiration from the neoclassical school of economics, particularly the Chicago School version made famous by Becker, Friedman and Stigler (van Overveldt 2007; Kaufman 2008a). The best known and most influential names include Robert Bork, Ronald Coase (with caveats noted below), Richard Epstein, Daniel Fischel, Edmund Kitch, William Landes and Richard Posner. Another related intellectual movement, often called "New Institutional Economics" (NIE), has also in important ways complemented the conservative Chicago School version of law and economics, as illustrated by the work of people such as Harold Demsetz, Michael Wachter and Oliver Williamson (Dow 1997; Furbotn and Richter 1997). In the world of policy-making, we see evidence of this U-turn in the rise to influence of neo-liberalism and the mounting pressure on governments from globalization and other forces to loosen their regulatory regimes in order to promote greater economic competitiveness, labor market flexibility, and job growth (Deakin and Wilkinson 2005; Prasad 2006). Not surprisingly, the field of labor and employment law has also lost considerable luster and one now reads articles in law reviews about the "death of labor law" (e.g., Hepple 1996; Estlund 2006).

The remainder of this volume is devoted to a detailed exploration of the pros, cons and consequences of the many different types of modern labor and employment regulation. Much of this analysis, in both its positive and normative aspects, will in some way build on 
or call upon the theoretical issues and points of view contained in the two law and economics (L\&E) movements birthed in the United States during the twentieth century. It seems useful, therefore, to provide here an exposition and review of these two opposing schools of analysis, with the idea that this provides a foundation and common reference point for the chapters that follow. Of more general interest, I am not aware that a similar comparative study of the two L\&E movements has been previously provided; indeed, to significant degree the two sides are like the proverbial ships passing in the night.

The modern L\&E movement is examined in the first part of the chapter; the second part describes the original L\&E movement. The discussion largely draws on a North American legal context and literature, although effort is made to selectively bring in important European contributions and perspectives. My representation of each paradigm is necessarily a stylized generalization; my claim, nonetheless, is that these generalizations reasonably capture the core features and propositions of both L\&E movements. Finally, for ease of exposition, I use the terms labor law and employment regulation as equivalent concepts and both are defined in a broad and generic sense to cover all common law, statute law and regulatory rulings that pertain to individual or collective aspects of employment. Particularly in the US, the collective and individual parts of employment regulation are often separately distinguished as "labor law" and "employment law," but here I combine them.

Neoclassical law and economics 
Most economists and legal scholars talk about the law and economics movement in the singular, with the idea there is only one (e.g., Miceli 2004). This law and economics movement is associated primarily with various Chicago economists and legal scholars, such as those mentioned above, and is grounded on traditional neoclassical microeconomics. Since the theoretical base of the second L\&E movement is neoclassical economics (NE), I henceforth refer to it as neoclassical law and economics (NL\&E). NL\&E is part of a larger project of "economic imperialism" in which traditional price theory is extended and applied to explain and evaluate various non-market institutions and behaviors, such as the family, fertility, crime and drug addiction (Lazear 2000; Van Overtveldt 2007).

The positive and normative analysis of law is one of the largest and most influential applications of economic imperialism. The modern law and economics project has its roots at the University of Chicago in the 1940s, through the work of Henry Simons and Aaron Director, but didn't blossom and take off as a formal movement until the 1970s. NL\&E is now widely represented in both economics departments and law schools, but the direction of intellectual trade - in keeping with the theme of economic imperialism -- remains heavily one-way; that is, from economics to law. Attention to labor and employment law was initially slow to develop among NL\&E scholars, (Campbell 1986), but in the last two decades the literature has expanded dramatically (see Schwab 1997; Donahue 2007).

Models and assumptions

The answers NL\&E gives on issues of employment regulation are heavily shaped by the way it frames the economic problem; the methods, theories and models it uses; and the 
positive and normative assumptions underlying these theories and models. Here is a thumbnail sketch (also see Collins 2001; Deakin and Wilkinson 2000, 2005; Miceli 2004; Posner 2007).

Efficient allocation of scarce resources. NE makes the efficient allocation of scarce resources the central economic problem (Schwab 1997). The idea is that resources of land (natural resources), capital, and labor are scarce but people's wants are largely unlimited, hence economies must allocate and use their resources in the most efficient way. An efficient (or Pareto optimal) allocation of resources is attained when it is not possible to reallocate these resources to make one person better off without at the same time making someone else worse off. An efficient allocation puts the economy on its production possibility frontier where it produces the maximum attainable amount of goods and services, an outcome that has led some in the NL\&E literature to translate the goal of efficiency into "wealth maximization" (Posner 2007). The pros and cons of employment regulation, in turn, are evaluated largely in terms of their effect on efficiency - laws that promote efficiency (getting to the production possibility frontier) are positively viewed and those that impede efficiency are negatively viewed.

Efficiency is defined in terms of consumers' interests. This second point is usually left implicit but needs highlight for what follows. Efficiency means the production and allocation of goods and services to maximize the welfare of economic agents; before this can become operational, however, the theorist must posit who the economic agents are. In principle, an economic agent is any human participant in the economy. For purposes of welfare and policy analysis, however, the near-universal practice in neoclassical economics is to assume that the utility functions society is trying to maximize belong to consumers - 
that is, the people who are ultimate end users of the final goods and services (Campbell,1983).

The efficiency of competitive markets. If the social goal is efficient production and wealth maximization, then what kind of economy is best at attaining this? Neoclassical theory claims to show that the most efficient form of economic organization is a free market ("Walrasian") economy in which all goods and services are traded in perfectly competitive markets. This principle is formally embodied in NE's First Fundamental Welfare theorem, also called the "Invisible Hand" theorem (Micheli 2004, p. 30). The Invisible Hand theorem states that the operation of demand and supply in competitive markets will, through the forces of individual self-interest and competition, automatically and without central guidance ("as if by an invisible hand") move the economy to the production possibility frontier. A corollary proposition is known as Say's Law: that is, the operation of demand and supply and flexible prices in a free market competitive economy will automatically move the economy toward a point of full resource utilization and, in particular, full employment of labor (Kates 1998). Thus, competitive labor markets lead to two highly desired end states: efficient allocation and full utilization of labor. Implicit in these two end states are two other outcomes that are frequently cited in the recent NL\&E literature as also highly valued: competitive markets allow a highly flexible and adaptive shift of labor resources in response to changing economic conditions, and competitive markets minimize cost and maximize productivity of labor. Law is important to achievement of all of these results since the perfectly competitive model hinges on fully specified, protected, and tradable property rights, as well as a supporting umbrella of fully specified and enforced contract and tort law. 
Fairness, justice and redistribution. The neoclassical perspective is that economics is a positive science that can meaningfully theorize about and make recommendations on efficiency, with efficiency being an objective property (given people's preference structure) with a well-defined meaning and measurement. Fairness and justice, however, are regarded as inherently subjective and ethical/metaphysical concepts (like beauty and charm) that lack a substantive basis and common unit of measurement. Neoclassical economics, therefore, does not include fairness or justice within the standard corpus of microeconomic theory, nor does NL\&E give them an explicit role in evaluating the pros and cons of law and regulation.

It would be incorrect to say, however, that NE and NL\&E ignore fairness and justice, or lack anything to say about them. NE and NL\&E in fact have four implications or predictions about fairness. First is that in the canonical Walrasian representation of NE achievement of efficiency in production and exchange is independent of fairness in distribution; this property is established by the Second Fundamental Welfare Theorem which states that in a competitive market system it is possible to achieve an efficient outcome regardless of the initial distribution of endowments (Miceli 2004, p. 30). Second, if the resulting efficient point on the production possibility frontier does not result in the distribution of goods and income society desires, the welfare maximizing solution is to redistribute initial endowments through lump sum transfers rather than by any interference or regulation of the market process itself or redistribution of goods and incomes after the fact (Collins 2001). Third, attempts to achieve fairness or redistribution through legal or regulatory means that disturb or constrain the competitive market process lead to an efficiency loss, thus implying existence of an efficiency/equity trade-off. Fourth, and 
finally, under certain interpretations a competitive market system actually leads to a double win - not only does such a system maximize efficiency but it also leads to outcomes that are fair and equitable. Posner (2007), for example, argues that it is immoral and unjust to waste resources in a world of great poverty and want, hence achieving efficiency is at the same time achieving a moral good. With regard to labor markets, a strain of thought going back to J.B. Clark (1899), principal originator of the marginal productivity theory, is that competitive labor markets lead to fair and just wage outcomes since workers are paid (on the margin) what they contribute to the value of production --called by Budd (2004) "marginal productivity justice."

Personal freedom, initiative and responsibility. Another virtue of a competitive market system, according to NE proponents, is that it promotes socially desired outcomes and behaviors. Chief among these are maximum personal autonomy, freedom and liberty in the economic realm of life, and strong incentives encouraging personal initiative in the discovery of new and improved methods of wealth production and in shouldering responsibility for one's economic choices and life success (Epstein and Paul 1985). In this regard, NE and NL\&E have a strong normative predisposition in favor of individualism (Friedman and Friedman 1980). Part of individualism is giving people as much room for choice as possible, free from constraint and coercion. A competitive market system is ideal because it decentralizes economic power, promotes and protects private property rights and use and disposition thereof, and gives people many alternatives with regard to basic life decisions, such as where to live, how to earn a living, and what to with one's time and goods. In this regard, an important principle to be promoted in the NL\&E view is freedom of contract (Trebilcock 1993). 
Freedom of contract promotes two valuable ends: first, by promoting trade and protecting the gains there from it channels scarce resources to their most productive use and, second, the voluntary making of contracts is presumed to enhance the welfare of both parties since otherwise one or both would not agree to the contract terms. This latter proposition provides a powerful argument against restrictive market regulations since on prima facie grounds they appear to block welfare-augmenting trade (Posner 1984).

Application to labor and employment regulation

Having sketched the theoretical foundation of NL\&E, I now use it to examine the pros and cons of various types of labor and employment regulation. First are the "cons," as they typically come first and are given more emphasis in NL\&E (Trebilcock 1993). To proceed, I will consider two broad classes of labor and employment regulation. For purposes of identification, I refer to the first as labor market regulation and the second as employment mandates. Although in practice the two overlap, in theory they are distinct.

Labor market regulation constrains or supplants in some direct way the operation of demand and supply and the coordinating role of flexible wages and thereby directly changes the negotiated terms of the labor contract. Examples include a minimum wage law; law to encourage collective bargaining as means to raise workers' wages; a child labor law; or an equal pay law for men and women in the same jobs.

Employment mandates stipulate that employers (or other third parties) provide or upgrade a particular term or condition of employment, either through direct employer provision or indirect provision (e.g., by government or unions) funded through taxes and 
contributions. They may shift either or both the demand and supply curves and thus indirectly affect the terms of the labor contact, but the labor market and coordinating role of flexible wages are still free to work out an equilibrium outcome. Examples include unemployment insurance, paid maternity leave, advance warning of plant closure, and equal opportunity in job assignments and promotions.

Labor market regulation. Two classic forms of market regulation are a minimum wage law and collective bargaining through trade unions. The latter regulates markets not through law per se, but through the institution of a trade union which the law encourages and protects.

The standard NL\&E evaluation of minimum wage laws and trade unions is illustrated in Figure 2.1, panel (a) and (b). Panel (a) and (b) represent two closely connected competitive labor markets for the same type of labor (Mincer 1976; Kaufman 2007a).

Absent any impediment, demand and supply yield the same equilibrium wage of $\mathrm{W}_{1}$ in both markets. This wage has all the efficiency and fairness attributes discussed above. In panel (a) now impose a minimum wage law or use the law to facilitate formation of a labor union, while neither is applied to panel (b). Panel (a) is called the "covered sector," panel (b) the "uncovered sector" (no minimum wage law, no union). Analytically, the effect on the two labor markets of the union or minimum wage is identical, at least as a first order approximation.

\{Figure 2.1. NL\&E Perspective: Economic Effects of Labor Market Regulation\}

In the case of a minimum wage, the law introduces a price floor into the labor market; in the case of collective bargaining a monopoly-like cartel is introduced. Both actions lead to 
a rise in the wage above the market level, such as from $\mathrm{W}_{1}$ to $\mathrm{W}_{2}$ in panel (a). A number of adverse things are predicted to happen.

First, the higher wage leads employers to cut back on their level of employment from $L_{1}$ to $L_{2}$ (point A to $B$ ), implying $L_{1}-L_{2}$ workers lose their jobs.

Second, the higher wage draws into the covered labor market more people who want to work, illustrated by the increase in the quantity supplied of labor from $\mathrm{L}_{1}$ to $\mathrm{L}_{3}$ (point A to C). But since available jobs are now only $\mathrm{L}_{1}$, the covered sector experiences disequilibrium and involuntary unemployment of $\mathrm{L}_{3}-\mathrm{L}_{1}$ (point $\mathrm{C}$ to $\mathrm{B}$ ).

Third, although not directly depicted in the diagram, the theory predicts that covered firms respond to the higher wage in several other ways that are also economically harmful. That is, firms suffer reduced profit margins and in some cases go out of business; they react by "overusing" capital in an effort to hold down labor cost by substituting capital for now more (artificially) expensive labor; they attempt to shift on to consumers part of the cost of the higher wage in the form of higher prices (or shorter hours, longer wait times, lower quality, etc.); and they substitute away from lower productivity workers (e.g., inexperienced teenagers, unskilled minorities) and toward higher productivity workers (e.g., mature women with more stable work histories, white males with more experience or education).

Fourth, some of the unemployed $\mathrm{L}_{3}-\mathrm{L}_{1}$ workers may eventually become discouraged by lack of jobs in the covered sector and shift their job search to the uncovered sector. ${ }^{\mathrm{i}}$ To the extent this happens, the labor supply curve in panel (b) shifts rightward and the equilibrium wage falls to $\mathrm{W}_{3}$ (point $\mathrm{D}$ to $\mathrm{F}$ ). Where all workers (presumptively of equal 
productivity) had earlier received equal wages, one group now gets the higher wage of $\mathrm{W}_{1}$ while another group gets a lower wage of $\mathrm{W}_{3}$.

Fifth, while it appears that perhaps things net out as some workers gain and others lose, in the aggregate the losers dominate. Among the evident losers are covered firms, consumers of covered sector goods, the laid-off and unemployed workers, and uncovered workers who now work at a lower wage. The major winner is the group of covered sector workers who keep their jobs and now get higher pay. In effect, the former groups have been "taxed" in order to redistribute income to the latter group. But there is another group that is also a loser, and this is a very large group that in fact includes everyone in the country. That is, all groups lose because the artificial increase in the wage leads to a general misallocation of resources and thus generates economic inefficiency. The fundamental NL\&E indictment of a minimum wage or trade union, therefore, is that by interfering with free market forces they cause society to move inside the production possibility frontier, thus imposing a "deadweight loss" of wealth on all members of society (Hirsch and Addison 1986). Not only is this outcome welfare-reducing, the idea that the government would deliberately foster monopoly and protectionism in labor markets seems perverse when it promotes antitrust and free trade in product markets (Posner 1984; Baird 2000).

Sixth, other second order and "ripple" effects from a market intervention such as a minimum wage law and collective bargaining may impose additional economic and noneconomic burdens. Examples include rigid wages (reducing the flexibility of the economy; preventing return to macroeconomic full employment), less firm-provided training, greater inequality of earnings among the workforce, more strikes and restrictive work rules, more criminal and underground economy activity (due to the greater number of unemployed), 
greater political pressure for all kinds of economic protectionism; and a greater division of society into fortunate "insiders" and unfortunate "outsiders."

Seventh, NL\&E points out that not only do these legal interventions in labor markets create and shift significant costs on to other groups in order to benefit a favored group, the great irony is that even the favored group may in the end be a loser (Rottenberg 1981; Booth,1995). This outcome can be seen as a particular case of the "law of unintended consequences." Thus, the social goal of a minimum wage law or trade union is to redistribute income to a particular group of workers. But what actually happens? If firms' labor demand is elastic (i.e., the quantity demanded of labor falls more than proportionately in response to an increase in the price of labor, as it might for teenagers or the unskilled), then a rise in the wage causes sufficient people to lose their jobs that the total amount of labor income (the "wage bill") earned by the workers is actually less than before. So, say the NL\&E critics, the unintended but often real effect is to try to solve poverty and low earnings by creating more unemployed workers!

Employment mandates. Legal mandates upon employers have multiplied in number and cost since the early 1960s, certainly in the United States but also in many other countries (Commission on the Future of Worker-Management Relations 1994). A mandate may require an employer to directly provide some valued good or service, such as one week notice of termination or portable vesting of pension benefits, or may require the employer to pay a tax or fee to a third party who provides the good or service, such as a government or union run unemployment insurance plan.

Are employment mandates a wise social policy? NE and NL\&E recognize that no blanket statement can be made on this matter, but it is fair to say that the presumption is 
against mandates and, therefore, the burden of proof is shifted to proponents who must demonstrate a compelling economic case for them (Trebilcock 1993; Collins 2000).

The skeptical to critical stance NL\&E takes toward employment mandates stems from the same core efficiency and equity arguments sketched above for direct forms of market regulation. The details of the argument differ somewhat, and are best understood with a modestly different diagrammatic analysis. Toward that end, consider Figure 2.2.

\{Figure 2.2. NL\&E Perspective: Economic Effects of an Employment Mandate\}

Figure 2.2 depicts a competitive labor market before the imposition of an employment mandate. As before, the equilibrium wage/employment level is $\mathrm{W}_{1} / \mathrm{L}_{1}$ (point A). Now assume the government requires all employers to provide workers with a good, such as health insurance. Two things happen: $:$.ii The first is that the labor demand curve shifts leftward, from $D_{1}$ to $D_{2}$. The reason is that at the given wage of $W_{1}$ the employment mandate raises the cost of labor to the firm and (like a tax) induces the firm to reduce employment. ${ }^{\text {iii }}$ The second effect is to shift to the right (downward) the market labor supply curve, from $S_{1}$ to $S_{2}$. The supply curve shows the wage rate at which each worker is just willing to provide labor; with the provision of the mandated good - presumed to provide additional utility to the employees - each worker should now be willing to supply the same labor but at a wage lower by the amount of money value of the mandate. If the employees give the mandate zero monetary value, the supply curve does not shift; the larger the value they attach to the mandate the larger the shift. Assuming the mandate has positive value, 
Figure 2.2 shows that the effect of the legal mandate is to yield a new equilibrium (point B) with a lower wage $\left(\mathrm{W}_{2}\right)$ and lower employment level $\left(\mathrm{L}_{2}\right)$.

What is wrong with this outcome? From a NL\&E perspective, the mandate leads to another form of deadweight loss in social welfare. The crucial assumption in generating this conclusion is that the cost of the mandate to employers is greater than the value attached to the mandate by workers. The reasoning is this: if in a perfectly competitive labor market the value of a mandate to workers (say $\$ 1 /$ hour) is greater than the firms' cost of providing it (say \$.50), then competition and self-interest would have led firms to already provide it (because the firms' cost of the benefit is $\$ .50$ but the employees are willing to accept a lower wage up to $\$ .99$ to get it) - implying the labor market will already be providing the mandated good. If the labor market is not providing the good, then it must be the case that the firms' provision cost $(\$ .50)$ is greater than the value to employees (say $\$ .25)$. In this case the cost of the mandate exceeds the value, the demand curve shifts more than the supply curve, and there occurs a welfare loss. Again resources are wasted (used inefficiently) and the economy is moved to a point inside its production possibility frontier.

\section{Market failure}

The fundamental analytical construct in NL\&E is the model of a perfectly competitive labor market (Addison and Hirsch 1997). Adopted in full form, this model leaves little-tono room for legal regulation of labor markets and enactment of employment mandates. But even the most ardent proponents of NL\&E readily admit that the competitive model does not always well represent features of real world labor markets (Friedman and Friedman 
1980; Posner 1984). Information can be difficult and costly to obtain, mobility from one job to another is sometimes impeded, workers and jobs are sometimes quite heterogeneous, and some labor markets have only a few buyers. Every such example where a real world market condition falls short of the theoretical ideal of perfect competition is called a market failure. Clearly, market failure opens up the potential scope and need for employment laws and mandates (Trebilcock 1993; Jolls 2006).

Market failure takes a variety of forms, including the following.

Imperfect information. The competitive model presumes that both employers and employees have complete and costless information regarding the labor market situation, the nature of the jobs and work to be done, and all other dimensions of the potential transaction. For example, the model assumes both the prospective employer and employee know the wage rates offered at other competing firms when, in fact, a good deal of ignorance usually exists about this due to the costs of search. Complete information is crucial because then every margin of the exchange gets priced at it true social (opportunity) cost which, in turn, guarantees that the resulting outcome is Pareto efficient. If information is incomplete and costly to obtain, both employer and employee lack knowledge about certain aspects or consequences of the bargain and will make choices that are ex post inefficient. If employees, for example, are unaware of the health hazards at work then they will not bargain for fully compensating wages, thus providing a rationale for government regulation of health conditions.

Asymmetric information. Asymmetric information is a special subset of incomplete information but is usefully distinguished because of the unique problems it causes. Asymmetric information in the employment relationship gives one party an 
informational advantage over the other; that is, either the employer or employee possess "private" or "hidden" information that is unknown to the other. As an example, the employer may know better than the job applicant that the job entails a high probability of accident, or the job applicant may know that she is frequently late to work but the employer is ignorant of this fact. One of the problems asymmetric information leads to is adverse selection (Miceli 2004), Adverse selection causes unanticipated negative results for one party in an exchange because due to hidden information they cannot screen out the purchasers who are most likely to abuse or take advantage of the good or service offered. Thus, companies that offer a generous health insurance program or liberal termination policy are penalized by adverse selection since they are likely to attract the employees who have greater medical or performance problems, causing a rise in their production cost and incentive to drop these practices. A solution is to have government mandate a market-wide health insurance plan or a just-cause termination policy.

Employer market power. Another labor market failure arises from factors that give the individual firm some degree of power to set non-competitive wages or conditions. This condition is usually referred to generically as monopsony power. The classic case of employer power is a "one company town" where the firm (a coal mine, textile mill, etc.) is the only buyer of labor in the local area. This condition is called a monopsony market, which is the labor market analog to a monopoly product market where the firm is the only seller of a good. The problem with monopsony is that the firm lacks competition for labor and "exploits" workers by paying a wage less that their marginal value to production, just as a monopoly firm exploits consumers by charging too high a price for the good (Manning 2003; Erickson and Mitchell 2008). Employers may have some degree of monopsony 
power in other market situations, such as oligopsony (only a few employers, such as two hospitals in one community), monopsonistic competition (many employers but with differentiated jobs and workers or some form of mobility cost), and dual labor markets (where forces of discrimination and social norms create a high wage "primary" labor market for favored groups of workers and a low wage "secondary" labor market where other groups are forced to find jobs).

The virtue of a competitive labor market is that the individual firm faces a perfectly elastic supply curve of labor -- because the firm is only one of many in the market and the workers are homogeneous and freely mobile -- and thus has no ability to set a wage or employment condition below the market rate. Three conditions, however, can make the firm's labor supply curve upward sloping, which give it some degree of market power and therefore ability to provide less than the going market rate. The first is fewness of firms; the second is some form of mobility cost (e.g., loss of training investment or seniority); and the third is when workers and/or jobs are differentiated. Whatever the case, the existence of employer power provides a rationale for giving workers some form of countervailing power, such as a union or minimum wage law.

Externalities and public goods. Externalities and public goods are closely related problems that arise from imperfectly delineated and expensive-to-enforce property rights (Cornes and Sandler 1996). If buyers and sellers are able to negotiate complete contracts that is, contracts that specify and enforce every possible feature and future contingency of an economic exchange - then supply and demand will successfully price all aspects of the exchange and competition brings about a Pareto efficient outcome (Cahuc and Zylberberg 2004). If property rights are not completely specified or cannot be perfectly enforced, 
however, then some of the benefits and costs of the exchange "leak out" and affect uninvolved third parties, thus leading to inefficient outcomes. An example of a positive labor market externality is when a firm mandates a no-smoking rule and the community saves money on health care cost; an example of a negative externality is when a firm uses child labor and degrades the quality of the nation's human capital. With a positive externality, the benefit realized by society (the social benefit) is greater than the benefit realized by the buyer and seller (the private benefit) leading to an undersupply of the good; in the case of a negative externality the social cost is greater than the private cost and the "good" is oversupplied (Addison and Hirsch 1997; Miceli 2004).

Closely related is a public good - a good or service where poorly defined property rights make it impossible to exclude users who have not paid for it (non-excludability) or, alternatively, where the amount consumed by one person does not reduce the amount available for others (non-rivalry). Because third parties can enjoy the benefits of the good without paying for it, they choose to be "free riders" which leads to underproduction of the good relative to the social optimum. An example of a workplace public good is employee voice - voice is undersupplied because the worker who makes a suggestion or complaint to the boss (e.g., an unsafe machine, excessive line speed) is likely to disproportionately suffer the cost (e.g., fired for being a troublemaker) while the benefits of the worker's exercise of voice are enjoyed by everyone (Freeman and Medoff 1984; Kaufman 2007a). When in the case of externalities and public goods individual action in the labor market falls short, a rationale opens up for government regulation or provision, such as a maximum hour law to restrict over-working and a just-cause termination policy to protect and encourage employee voice. 
Imperfect decision-making. Market failure can also arise due to imperfect decision-making on the part of economic agents. The competitive market model assumes people make optimal choices, given the information and alternatives known to them. This means that their decision making is consistent, self-interested, individualistic, far-sighted, and maximizing (Trebilcock 1993, Sunstein 2000). Violation of any of these assumptions in a systematic broad-based way among economic agents leads to problems. For example, if people do not maximize then their choices will fall short of the best attainable and some resources or opportunities will be wasted. Similarly, if people's choices are influenced by what others do then a form of externality is introduced; while poor choices may arise if people are myopic (lack foresight), have irrational preferences (an inconsistent ranking of alternatives), are swayed by emotions, or do not act in their own best interest (i.e., forego a "merit good," such as wearing safety glasses). Workers, for example, may systematically underestimate the probability of injury, get caught up in a "rat race" and work excessive hours, or let non-rational sexual desires drive them to harass fellow employees. In each case employment regulation may improve welfare, such as a workplace safety law, overtime law, and ban on sexual harassment.

Countervailing arguments against employment regulation and mandates

The existence of market failures opens the door in neoclassical economics and NL\&E to the possibility that employment regulation and legal mandates may be efficiency enhancing and thus desirable on economic grounds. For a variety of reasons, however, the regulation door in NE and NL\&E typically swings open only reluctantly, by a small amount, and only 
in selective and well documented circumstances. Their basic stance regarding proposals for labor market regulation and mandates is "guilty until proven innocent," which is to say the null hypothesis is they are an unwise idea and it is up to their proponents to make a convincing case to demonstrate the contrary. Seven lines of argument are put forward in support of this position.

Market failure: spotty and superficial. The first line of defense is the NE/NL\&E contention that broadly viewed market failure is not a serious or widespread problem. Thus, NE and NL\&E proponents admit that as a real life matter information is incomplete and asymmetric, in some cases labor supply curves to firms are upward sloping, and sometimes firms break promises to workers, but they also claim that these problems are like a mild skin disease - mostly on the surface and in most cases not serious enough to require corrective action (Friedman and Friedman 1980; Posner 1984).

The efficiency of the common law. A second line of defense is the contention that the common law has evolved over time in ways that are aligned with and support economic efficiency, thus removing the need for special labor legislation (Rubin,1983; Posner 2007). When labor resources are wasted due to mis-structured law, either the employer or employee has a financial incentive to challenge the law in court - a process that over time winnows out bad law and promotes good (efficient) law.

Government failure is worse than market failure. Even if labor markets have significant imperfections, NE proponents argue that the "cure" - government intervention may be worse than the "disease.", That is, government intervention in the form of protective labor laws, social mandates, and regulatory agencies often entail large 
bureaucracies, expensive compliance costs, rigid rules, and extensive corruption and waste that may impose far larger costs and losses in social welfare (Coase 1992).

Regulatory capture and rent seeking by special interests. Another critique of employment regulation is that it is championed as a means to promote the public interest but in fact is either designed or subverted to promote sectional interests of specific groups and institutions through rent seeking and regulatory capture. Rent seeking occurs when groups devote resources to gaining preferential laws and regulations that provide them with monopoly rents; regulatory capture occurs when a regulatory body is subverted to serve the interests of the regulated party rather than the public. NL\&E critics of employment regulation cite numerous examples where the law and legal process are (allegedly) used for these wealth-reducing purposes. One example is when unions support minimum wage laws - ostensibly, it is charged, to help reduce poverty but is really to reduce the threat of lowerwage nonunion competition (Rottenberg 1981); a second is when members of "protected groups" (e.g., racial minorities, women) use anti-discrimination law not to correct injustices but pressure firms through actual and threatened court suits for higher pay or security from termination (Donahue and Seligman 1991).

The Coase theorem and private bargaining. The "Coase theorem," inspired by Coase (1960) but originally named and articulated by Stigler (1966), provides a powerful NL\&E argument against government regulation. The theorem asserts that in a situation of zero transaction cost (defined more fully in the next section) individual economic agents have an incentive to use private bargaining to re-assign resources to their most productive use. The implication is that labor market failures, such as arise from externality and public good problems, do not necessarily require a government law or regulation since the parties 
involved can often work out through negotiation and compromise a reasonably efficient solution (Miceli 2004).

Maximum of liberty and freedom of contract. NL\&E proponents believe competitive markets, even if marred with certain blemishes and shortcomings, should nonetheless be protected from government regulation as much as possible because they promote highly valued normative ends, such as personal liberty, freedom of contract, and individual initiative and responsibility. Economic freedom, they argue, promotes and supports political freedom (Friedman 1962; Epstein 1984).

Empirical evidence. Putting aside theoretical arguments, NL\&E proponents claim the bulk of the empirical evidence on the relationship between labor market regulation and economic growth also supports their minimalist position. A large number of studies have examined the cross-sectional relationship between extent of labor market regulation in a political jurisdiction (state, province, country) and a measure of economic performance (e.g., output or productivity growth). The bulk find a negative relationship, indicating more regulation inhibits wealth creation (e.g., Koedijk and Kremers 1996; Barro 1997; Hall and Jones 1999). Civil law countries, which have greater statutory regulation of employment, also have lower average growth rates than common law countries (Scully 1992).

Institutional Law and Economics

I now turn to what Hovenkamp (1990) identifies as the First Great Law \& Economics Movement. This movement for the most part languishes in obscurity and neglect in the modern-day law and economics literature. Indeed, as earlier indicated, most people speak 
of L\&E in the singular. Illustrative of the neglect the first law and economics movements suffers, one of its most active and influential areas of scholarship and policy activism was in the area of labor and employment, yet, to the best of my knowledge, no modern scholarly article or book has done a theoretically substantive review and development of this literature. In what follows I take a first step in this direction, although given the nature of my assignment and the constraints of space it is necessarily suggestive. To some significant degree, this exposition is also heavily grounded on my own interpretations and constructions, as developed in previous books and articles.

People, ideas, and historical context

The First Law and Economics Movement was an American development spanning roughly the period 1885-1940. It had substantial European roots, however; most particularly in Germany where economists of the historical school were endeavoring to integrate law into economics (Pearson 1997; Mackaay 2000). The first American law and economics movement represented a fusion of two early $20^{\text {th }}$ century intellectual developments: institutionalism in economics and legal realism in law (Fried 1998). For both expositional and theoretical reasons, I henceforth refer to this movement as Institutional Law and Economics (IL\&E). There remains a small but active contingent of economists and legal scholars writing in the IL\&E tradition per se (e.g., Samuels and Schmid 1981; Oppenheimer and Mercuro 2005), although employment issues do not prominently figure in this literature. 
Much of what comprises the "traditional" post-World War II field of labor law, particularly the collective relations part, also has significant roots in the First Law and Economics movement, as does the field of industrial relations. As described below, a fundamental proposition in IL\&E is that since labor markets and the employment relationship deal with a uniquely human commodity — labor — they require a more complex, interdisciplinary, and social-oriented theory to adequately understand them. This proposition, in turn, is reflected in the insistence of many traditional labor law scholars that their field has a large degree of autonomy from the common law (Wedderburn 1988; Davies and Freedland 2000); it also explains their skepticism/hostility to the imperialistic and market-oriented nature of NL\&E theory and the strong free market ethos of NL\&E policy prescriptions (Collins 2000; Deakin and Wilkinson 2005). Also evident is greater emphasis given to and acceptance of collective forms of behavior and social control.

The IL\&E movement can be roughly divided into two phases: the first is an early formative or "pre-organized" period, lasting about twenty years in which key ideas and conceptual building blocks were advanced, and the second is the consolidated or "organized" period when the movement coalesced into a self-conscious and self-identified entity with a significant intellectual output and influence on policy (Yonay 1998). The IL\&E movement peaked in power and influence in the decade 1935-1945, marked by the legislative triumphs of the New Deal period, and then went into decline. In the labor and employment area, the IL\&E ascendancy was marked by enactment of the triumvirate of landmark bills: the Social Security Act (SSA), National Labor Relations Act (NLRA) and Fair Labor Standards Act (FLSA). This legislation was supported by a wide swath of the economics community 
(Prasch 1998), including labor economists Paul Douglas and Harry Millis of Chicago (Millis 1935; Douglas 1938).

The IL\&E movement's subsequent loss of influence and momentum after World War II was signaled by the revival of neoclassical economics and enactment of conservative-inspired labor legislation, such as the Taft-Hartley amendments to the NLRA. The movement also lost momentum partly because its successes reduced some of the most obvious and compelling reasons for being; the emergence of problems, excesses and public dissatisfactions with parts of the New Deal policy program; and because most its big thinkers and doers died or retired. Emblematically, the focal point for the IL\&E research and lobbying program for expanded labor law was the American Association for Labor Legislation (AALL) - created in 1905 at the end of the first phase and allowed to expire in 1942 at roughly the end of the second phase (Moss 1996).

The first phase of the IL\&E movement began in the mid-1880s and extended into the early 1900s. The most visible starting point is the founding of the American Economic Association (AEA) in 1885 under the primary leadership of Richard Ely (Rader 1966). The AEA was intended by Ely to be a center for development of a new economics, largely inspired by the historical and social economics popular in Germany and (to lesser extent) England (Koot 1987; Kaufman 2004a). The new economics in America a generation later evolved into institutional economics.

The movement for a new economics was an outgrowth of the "Methodenstreit" (war over method) that broke out in numerous countries in the 1880s between the orthodox adherents of classical/neoclassical economics and a quasi-heterodox band of intellectual insurgents (Dorfman 1949; Pearson 1997). The new economics was developed as an 
alternative approach on three fronts. With regard to methodology, it promoted a more inductive, empirical and interdisciplinary research program. In the area of theory-building, the new economics sought to develop a more organic, dynamic and realistic theory of the capitalist economy which gives greater weight to human agency, human and market imperfections, legal, social and business institutions, and ethical considerations of public interest and social purpose. And, with regard to policy, it represented an attack on the laissez-faire implications of classical/neoclassical theory and an endeavor to provide an alternative positive intellectual rationale for expanded government economic regulation, trade unionism, and redistribution of rights, power and wealth (Rutherford 2001; Kaufman 1997; 2005).

The oppositional and reformist nature of the new school of economics, and its substantial concern with labor issues, is well indicated in the statement of principles Ely drafted for the AEA. It read, in part:

We regard the State as an educational and ethical agency whose positive aid is an indispensable condition to human progress. While we recognize the necessity of individual initiative in industrial life, we hold that the doctrine of laissez-faire is unsafe in politics and unsound in morals... We hold that the conflict of labor and capital has brought to the front a vast number of social problems whose solution is impossible without the united efforts of Church, State and Science. (Rader 1966, p. 35)

Also ranking as a founding moment was publication in 1887 of economist Henry Carter Adam's influential essay "The State in Relation to Industrial Action" (reprinted in Dorfman 1969). He sets out the leit motiv of what would later become IL\&E when he says, "It should be the purpose of all laws, touching matters of business, to maintain the 
beneficent results of competitive action while safeguarding society from the evil consequences of unrestrained competition" (p. 86). Adams more tightly links economics and law in his 1896 AEA presidential address, entitled "Economics and Jurisprudence" (also reprinted in Dorfman 1969). The purpose of law, he states, is to "formulate those rules of conduct essential to the realization of justice" (p. 138) and then observes that laissezfaire must be replaced by active social reform since "the workings of self-interest in the industrial field do not in all respects appear to be in harmony with the ideals of justice." Adams' case for economic reform and regulation is based not only in correcting injustice, however, but also on improving economic efficiency, per his observation that "there are many who profess to see that it [the workings of self-interest] places in jeopardy material progress itself." (p. 143).

Institutional economics (IE) and legal realism (LR) started to form in the early 1900s and came into their own in the 1920s. As earlier indicated, they went into significant decline after World War II, although in recent years both a "new" institutional economics and a "new" legal realism have appeared (Dow 1997; Farber 2001). The new institutional economics, however, is more neoclassical in orientation and policy stance, although in certain respects Coase (in particular) has at least one foot solidly in the early institutional camp (Medema 1996).

Frequently IE is said to have had three founders, Thorstein Veblen, Wesley Mitchell and John Commons, along with several other important contributors, such as Walton Hamilton, John Maurice Clark, Morris Copeland, and Rexford Tugwell (Rutherford 2001). Several of these people, such as Veblen and Mitchell, had only modest interest in the interface between law and economics and largely fall out of the story told here. Far more 
central are Commons, Hamilton and Clark, with the former occupying center place in what follows.

The heart of early IE in labor was at Wisconsin. Ely brought Commons to Wisconsin in 1904 and Commons assembled in the 1920s the largest group of labor economists at any American university. Commons made the law a central part of his version of IE, as indicated in the title of his book Legal Foundations of Capitalism (1924), and he explicitly sought to develop the interface between law and economics, per the title of a 1925 essay in the Yale Law Review titled "Law and Economics." Commons also figures large in the L\&E of labor since he was at the time not only the leading labor economist in the nation but also the foremost academic authority on labor law, per his text Principles of Labor Legislation ( $1^{\text {st }}$ ed., 1916, with Andrews). Commons was one of the great social reformers of the pre-New Deal era and a life-long opponent of laissez-faire, seeing it as a cause of great human suffering and impulse for radical politics and socialist revolution. Commons' reformist but pro-capitalist stance is indicated by his remark that his life goal as an institutional economist was to "save capitalism by making it good" (Commons 1934a, p. 143); his reformist credentials in labor are also revealed by the remark of Kenneth Boulding that "Commons was the intellectual origin of the New Deal, of labor legislation, of social security, of the whole movement in the country toward a welfare state" (1957, p. 7).

Legal realism shared many of the tenets of IE but came to them from the subject of law (Letier 2003; Sunstein 2004). The roots of LR are often traced to jurist Oliver Wendell Holmes (Fried 1998). Prominent writers in LR in the early twentieth century included Robert Hale, Roscoe Pound, Wesley Hofeld, Karl Llewellyn, Felix Cohen, and Jerome 
Frank. The LR school was a reaction against excessive formalism in law, just as IE was in economics, and LR also had a base in pragmatism and multidisciplinary studies. More importantly, however, LR was also a reaction against the laissez-faire constitutionalism of the Supreme Court in the early twentieth century and its sweeping limitations on state regulatory power under the doctrine of "substantive due process," particularly as applied to employment regulation (McCurdy 1984). These decisions, in part, rested on or were parallel to tenets of orthodox economics, such as free competition and freedom of contract, leading Robert Hale to caustically remark (quotations from Fried 1998), “The practical function of economic theory is merely to prove to statesmen the wisdom of leaving [economic] matters alone" (p. 45). In place of the laissez-faire dogmatism of orthodoxy, Hale counseled that "the question of the maintenance or the alteration of our institutions [e.g., laws and regulations] must be discussed on its pragmatic merits," (p. 89), requiring in turn scientific study of "the function performed by the law in the production and distribution of wealth" (p. 10).

\section{Key IL\&E assumptions}

The early developers of IE and LR were engaged in a three-fold exercise: development of an alternative theoretical base for economics and L\&E, use of this alternative theoretical base to craft and implement a program of social reform and expanded market regulation, and promulgation of a more humanistic ethical credo to guide research and policy. They never succeeded in formalizing, or even well articulating, the first part - an alternative theoretical paradigm. But a synthesis of this large and not always commensurable literature 
suggests the following set of fundamental IL\&E assumptions, which has an orientation to labor and employment issues (Kaufman 1997, 2004b, 2005, 2007b, c).

Purpose of an economy. The purpose of an economy is to serve human ends. One way it does this is to operate efficiently so people have the maximum of goods and services. But the grand objective of human existence is not efficiency (the "largest GDP") but the "good life" (Slichter 1931). What exactly constitutes the good life is subject to debate, but it certainly includes greater amounts of economic security, procedural and distributive justice, and opportunities for self-development and self-actualization than are provided by the efficiency criterion alone (Sunstein 2004). IL\&E proponents would agree that economic policy should seek to get society on the production possibility frontier but only if the "goods" (or "social wealth") included in calculating the frontier include not just GDP-type goods but also goods such as economic security, social justice, fulfilling jobs and healthful working conditions. Without this broader perspective, the interests of people (including workers) get subordinated by a narrow efficiency/materialist welfare objective to doing what is best for the economy, rather than structuring and operating the economy to benefit people.

Liberty. The NL\&E version of liberty is negative liberty - i.e., absence of restraint - which leads them to advocate minimal government market regulation. From an IL\&E perspective, however, "liberty to starve" or "liberty to work a fourteen hour day" is not an attractive conception of liberty; likewise, to say that both a poor person and rich person have an equal freedom to quit a dangerous or dirty job if they do not like it greatly empties the concept of freedom of meaningful significance (Hale 1926; Samuels, Medema and Schmid 1997; Fried 1998). Seen in this light, the "freedom of contract" trumpeted by 
NL\&E may be a façade that hides the whip of economic coercion wielded by one person with control of strategic resources (e.g., an employer offering scarce job opportunities) over another person who has few resources and must trade or go hungry (e.g., an employee with dependent family members and no alternatives source of income). Proponents of IL\&E, therefore, base their theory and policy program on a concept of positive liberty. Each person has positive liberty when they have the resources needed to command the essentials of life, thus giving them not only the legal space to construct their life but also the economic space (Sen 1999).

Labor is human. In NL\&E, labor is modeled as not substantively different from other factor inputs or goods and services and, hence, labor markets are also modeled as not substantively different from other kinds of markets (Addison and Hirsch 1997). Further, from a welfare perspective NL\&E views labor solely as a factor input that does not itself count in social welfare but rather contributes to welfare only to the extent it is efficiently used to produce final goods and services for consumers. In IL\&E, explicit recognition is given to the fact that labor services are embodied in human beings (Commons 1934b; Spector 2006). This fact, it is maintained, fundamentally changes theorizing about labor (described below); it also calls attention to the fact that if the goal of an economy is to improve human welfare then people's welfare as workers should be given consideration above and beyond their contribution to production and satisfaction of consumers' interests.

Ownership and property rights. Institutional economics is built on the concept of ownership and correlative concept of property rights, per the statement of Commons (1934b, p. 5) that "ownership becomes the foundation of institutional economics." Property rights also figure prominently in the NIE (Furubotn and Richter 1997; Coase 1992); they 
have also been extensively examined by several prominent NL\&E writers (e.g., Demsetz).Without prior specification of property rights and ownership fundamental economic constructs such as commodities, production functions, and demand and supply curves have no basis. These property rights also include not only ownership of economic goods but fundamental human and social rights.

Institutions. Institutions are bodies of rules, both formal and informal and explicit and tacit, that are built out of property rights (broadly defined) and define the rules of the economic game and the constraints, opportunity sets, incentives, and strategic interdependencies faced by economic agents (Coase 1992; Furubotn and Richter 1997). All economic activity is "institutional" since its takes place within and is structured and guided by human-made institutions; it is also inextricably linked to concerns of fairness and status since the laws, rules, norms and customs created and enforced by institutions serve in part to apportion justice and social standing.

Sovereignty. Economics is always "political economy" because the institutions and their derivative rules which guide and structure economic activity are in part determined through a political process in which people individually and collectively seek to capture and use the power of sovereignty to shape the institutions and rules to promote their interests (Commons 1950).

Behavioral/Social model of the human agent. People are modeled as largely purposeful and self-interested, but decision-making is subject to bounded rationality and behavior is influenced by emotions, social interdependencies, and ethical precepts (Kaufman 1999b; Sunstein 2000; Schmid 2004). A key part of bounded rationality is that many future events are subject to fundamental uncertainty -- that is, cannot be represented 
by even a probability distribution; another key part is the distorting effect imparted to behavior by emotions such as anger, hate, love and pride.

Transactions and transaction cost. A transaction is a legal transfer of ownership; transaction cost is the real resources used to effectuate and enforce this transfer (Commons 1934b; Coase 1937).

Modes of coordination. Economies have alternative institutional modes for coordinating transactions; the two most important for theory are (1) markets and price, and (2) organizations and command (Williamson 1985; Kaufman 2003).

Power. Power is the ability to satisfy one's desires and obtain a greater share of an institution's scarce goods (material and non-material). Power is influenced by how greatly an economic agent needs/wants an outcome and how long the agent can hold out in the bargaining vis a vis the other side (Samuels, Medema and Schmid 1997).

Reasonable value. Economic agents individually and collectively have a notion of what is fair and reasonable; whenever an outcome/ process falls outside the bound of reasonableness they undertake action to alter the institutional matrix of rules and rights (Commons 1934b; McIntyre and Ramstad 2002).

Critique of the competitive model

The IL\&E analysis of labor markets and employment relationships proceeds in two steps. The first is a critique and deconstruction of the competitive labor market model that forms the core of the NL\&E paradigm; the second is construction of an alternative model of the labor market and employment relationship that provides a more positive - but still 
delimited -- place for labor and employment regulation. Both steps proceed on the basis of one fundamental proposition: that labor is human and not a commodity (Budd 2004;

Kaufman 2004). This proposition, I note, is the cornerstone for the International Labor Organization (ILO) and its program of international labor standards, for the first of nine principles listed in the ILO's constitution reads: "Labor should not be regarded as a commodity or article of commerce" (ILO.org). Elsewhere, I have also made the case that this proposition also provides the positive and normative foundation for the field of industrial relations, where in my interpretation industrial relations represents what is in effect the labor subfield of institutional economics (Kaufman 2004a).

The core of NL\&E is the competitive model of labor markets, and this model gives rise to the neoliberal agenda of free(er) labor markets and deregulation of the employment relationship. Various qualifications and extensions, as just reviewed, soften and in some cases overturn the competitive model's negative verdict; nevertheless, when used as the starting point or baseline for theoretical analysis it inevitably gives the upper hand to opponents of regulation and puts proponents in a weaker, defensive position. Some critics of NE charge it has not only a free market bias but also an anti-labor bias, per the comment of Jospeh Stiglitz (2000, p. 3), that, "it might seem as if the fundamental propositions of neoclassical economics were designed to undermine the rights and position of labor."

Recognizing these biases, the early participants in IL\&E, as well as major figures in post-World War II industrial relations, spent considerable effort trying to displace or discredit the competitive model of labor markets (Commons 1919; Taylor and Pierson 1957). This effort, as judged by most economists, largely failed and the competitive model remains the paradigmatic core of NE, albeit surrounded by a rapidly expanding "protective 
belt" of secondary theorizing (Cahuc and Zylberberg 2004). Recent developments in IE theory, however, reveal that the competitive model has, in fact, a deep internal contradiction that appears to challenge its logical coherence, thereby calling into question the foundation on which NL\&E is built (Kaufman 2007d; 2008b).

The logical contradiction arises by considering the consequences of transaction cost for the competitive model. The concept of a transaction was first developed by Commons (1934b, p. 55) who defined it as a "legal transfer of property rights," the concept of transaction cost was then independently developed by Coase (1937) and formally extended by Williamson (1985) and others in the NIE. As such, it is a clearly an IE concept, illustrated by the fact it is still today widely omitted from leading microeconomics and labor economics textbooks, such as Varian (2002) and Ehrenberg and Smith (2006). It is omitted in part because neoclassical price theory assumes market exchange proceeds with zero cost, so transaction cost effectively drops out of the analysis (Dow 1997; Coase 1992). As one example, the logic of positive transaction cost implies that a perfectly competitive labor market cannot exist on the pure plane of theory. This result is fundamental since it makes derivation of a demand and supply diagram impossible, thus seriously crippling the major theoretical tool NL\&E uses to critique labor law and employment regulation (Kaufman 2008b).

A principle of IE is that production and exchange, other things equal, are either coordinated by markets and price or, alternatively, organizations and command, depending which entails least cost. It follows that if transaction cost is zero in a perfectly competitive economy then market coordination is everywhere the most efficient and firms (a system of command coordination) vertically disintegrate until all firms (and other production units) 
are one person operations in the form of sole proprietorships, independent contractors, and family farms. With this result in mind, Coase remarks, "In the absence of transaction cost, there is no economic basis for the existence of the firm" $\left(1988\right.$, p. 14). ${ }^{\mathrm{v}}$

The implication of this result is fatal for the logical coherence of the competitive labor market model. A labor market, as conventionally conceived, is a trading area where employers' demand people to provide labor services; household members offer to be employees and provide labor services; and flexible wage rates match up the two. In this spirit, Milgrom and Roberts state, "The study of labor markets, employment, and wages is a major element of standard neoclassical economics" (1992, p. 327, emphasis added). But, if all firms are one person units, they have no demand for employees and, thus, no reason exists for either a labor market or employment relationship. The two disappear, as does the concept of a "wage." These firms instead acquire labor services in the form of intermediate goods produced by other one person production units (say operating as independent contractors or sole proprietor firms) coordinated by price (not wage rates) in product markets.

We see, therefore, that the assumptions of the perfectly competitive labor market model preclude as a matter of logic the very object it seeks to theorize. The model, and the corollary labor demand and supply diagram, do not have a coherent microeconomic foundation and thus are to some degree ad hoc. Further, and more importantly, this conclusion means that labor markets are always and everywhere imperfect and that an employment relationship only exists when there is market failure (Kaufman 2008b). Labor market imperfections and failures are not occasional or superficial problems but are 
endemic and serious; otherwise, labor markets and very large multi-person firms would not exist.

I should note that this conclusion does not mean that IE advocates scrapping altogether the competitive model and labor demand and supply diagram, as they are admittedly insightful tools for research and pedagogical purposes. The goal, rather, is to further circumscribe the reach and power of the model by demonstrating it does not rest on a solid microeconomic foundation, thus opening larger space for theories of imperfect competition and thereby leveling the playing field for the IL\&E side.

IE demonstrates that the model of a perfectly competitive labor market is a logical non sequitur. This is an act of deconstruction. Next is the task of construction and, in particular, development of a positive theoretical case for employment regulation.

Toward that end, I briefly present four rationales, based on IL\&E concepts, for why labor and employment regulation can advance economic efficiency. I focus on efficiency in order to most directly challenge NL\&E; other welfare goals are also noted, however. The discussion makes use of the three graphs depicted in Figure 2.3. [Located on p. 48.] Panel (a) shows a model of an imperfectly competitive labor market (e.g., some version of monopsony); panel (b) shows a competitive labor market model at the aggregate (national) level; and panel (c) shows a competitive labor market for a particular occupation or grade of labor. The analysis selectively makes use of all three diagrams. 
The first rationale for labor and employment regulation is that workers suffer an inequality of bargaining power because imperfect labor markets and a lopsided distribution of resources and rights puts employers in the dominant position in wage bargaining and the individual worker in a weaker and dependent position (Commons and Andrews 1936; Kaufman 1989; Klare 2000. See Kennedy, 1982, for a critical analysis). With inequality of bargaining power, market competition cannot fully protect the wages, conditions and treatment of labor and thus some countervailing institutional mechanism must be introduced to ensure efficiency, equity, and due process. The primary social purposes are, first, economic protection of workers and, second, political democracy in workforce governance. Here are the classic IL\&E rationales for employment regulation.

In developing the idea of inequality of bargaining power, I proceed in two steps: The first is to consider the role of imperfect competition in labor markets, and the second is to consider the role of lopsided resources and rights. The two are distinct and need to be treated separately.

Imperfect competition. A situation of equal bargaining power exists in a competitive labor market since both employer and employee are wage takers, meaning neither has power to raise or lower the wage (and other conditions) above or below the competitive market rate. This yields both efficiency and fairness (marginal productivity justice) and the market provides full protection to workers. It does so through two means: workers can, with zero cost, quit and find jobs elsewhere ('vote with their feet') and competition forces firms to provide "optimal" terms and conditions of labor in order to recruit and keep a workforce. 
But what if labor markets are imperfect? In theory, an imperfect market may give the power advantage to either the employer or employee. Although both can occur, the IL\&E position is that most often it is the workers - particularly those with fewer skills, less education, or from disadvantaged groups -- who suffer unequal bargaining power. The reasoning is simple: who feels the greater pressure to reach an agreement and fill the job, the company or the worker? And which party has the greater resources and alternative options to fall back on if they do not reach agreement? In most circumstances, the obvious answer is the company, particularly when the usual overhang of excess labor supply in the job market is factored in (Taylor 1995). In this situation, early IL\&E proponents thought it was obvious that in wage bargaining between US Steel and the individual worker the imperfections in the labor market and superior "withholding ability" give the employer the distinct power advantage and ability to gain terms and conditions of employment that favor its interests. This occurs both in the external labor market where the employer exercises some degree of monopoly power in wage determination and in the governance system of the firm (the internal labor market) where the employer exercises some degree of autocratic power to craft, administer and enforce the rules of the workplace in a unilateral and sometimes arbitrary and unfair manner. Employment regulation, therefore, serves to protect the underdog, level the playing field, ensure industrial democracy, and create a balanced, humane employment system (Summers 1979; Dau-Schmidt 1992; Weiler 1990; Budd 2004; Kaufman 2007b).

The IL\&E position is that in both theory and practice labor markets are always and everywhere imperfectly competitive; hence, internal firm governance systems are also to some degree employer dominated (Block, Berg and Belman 2004). Several reasons can be 
cited. First, we have noted that a labor market and employment relationship can only exist with positive transaction cost. Positive transaction cost, in turn, arises from conditions of bounded rationality which, in turn, lead to incomplete contracts, imprecisely defined property rights, and gaps in legal enforcement of these rights. Hence, external and internal labor markets are unavoidably the site of a host of contracting imperfections, as recently emphasized in the modern literature on problems of principle-agent, moral hazard, strategic bargaining and adverse selection (Miller 1991; Bowles and Gintis 1993; Cahuc and Zylberberg 2004).

Second, a crucial assumption in the competitive model is that both individual firms and workers are wage takers, which is to say the wage is set by impersonal market forces and is outside the control of any agent. But IE shows that employers always and everywhere have some ability to set the wage (and other terms, conditions, and rules), at least as long as labor services are embodied in human beings. An essential condition of the competitive model is that labor is a homogeneous (undistinguishable) commodity. But this condition is violated by the very nature of the employment relationship. The reason is that the labor services are embodied in the worker (a form of indivisibility) and cannot be separated at the time of sale; thus the worker and employer of necessity form a personal relationship at the point of production (Prasch 2003). This fact distinguishes "outsiders" from "insiders," which along with search and mobility costs due to imperfect information (an attribute of positive transaction cost), makes incumbent employees a preferable and frequently less expensive source of labor services for firms than job candidates in the external labor market. 
Hence, workers are not homogeneous but heterogeneous, leading to a situation of monopsony -- broadly defined to include oligopsony, monopsonistic competition, and other market situations with costly mobility -- in which the labor supply curve to the firm is upward sloping (Card and Krueger 1995; Bhaskar and To 1999; Manning 2003; Erickson and Mitchell 2008). This is illustrated in panel (a) of Figure 2.3 by the rising supply curve $\mathrm{S}_{1}$, accompanied by a rising marginal cost of labor curve $\mathrm{MCL}_{1}$. In this labor market, the firm sets employment at $\mathrm{L} 1$ (where $\mathrm{MRP}_{1}$ intersects $\mathrm{MCL}_{1}$ at point $\mathrm{A}$ ) and pays a wage of $\mathrm{W}_{1}$ (given by the supply curve at point $\mathrm{B}$ ). This wage is lower than the competitive wage $\mathrm{W}_{2}$ (point $\mathrm{C}$ ), is determined by the firm rather than the impersonal forces of demand and supply (although they set upper and lower limits), and gives rise to exploitation of labor, typically defined as the difference between the workers' marginal contribution to production and the wage (points A-B). Alternatively, the firm may pay a competitive wage but exploit workers by reducing other terms and conditions of employment, such as benefits or safety expenditures; another option is to exercise its power through oppressive or onerous work supervision and discipline.

IE claims, therefore, that: (1) the homogeneity condition is always violated in an employment relationship (or leasing arrangement, etc.), so by definition labor markets are imperfect; (2) with an upward sloping labor supply curve, the individual firm gains some market power to set the wage, implying wage rates are always and everywhere a form of administered price and labor markets always and everywhere feature some element of employer control and potential wage exploitation and workforce autocracy; and (3) yet again the competitive demand and supply diagram deconstructs since with any element of employer power in the labor market it is impossible to derive a well-defined, continuous 
market labor demand curve. That is, in the monopsony diagram the firm has a well-defined marginal revenue product curve but not a well-defined firm/market demand curve, just as with product market monopoly the firm has a well-defined marginal cost curve but not a well-defined supply curve.

In passing, note that IE is not denying that at some broad level there is an inverse relationship between the price of labor and the quantity demanded. As Becker (1962) has shown, the law of demand is a fundamental fact of scarcity and is not a unique conclusion of any one theory, implying the existence of some type of negative employment effect is not discriminating evidence in support of the NE competitive market model. Rather, the real issue separating IE and NE is the tightness and sensitivity of this relationship.

NE price theory posits a monotonic, unique, well-defined inverse relationship between the wage and quantity demanded of labor - a product of complete contracts, a commodity theory of labor and perfect competition, while IE posits that the demand relationship has gaps, a certain degree of indeterminacy (a demand "band" instead of a curve), and possibly a vertical or positive-sloped section over a certain range, all due to a human theory of labor, incomplete contracts, imperfect competition, efficiency wage effects, etc. Thus, the zero/positive employment effect of a minimum wage found by Card and Krueger (1995) is entirely compatible with IE theory but not a straightforward version of NE theory.

Unequal resources and rights. Labor may also suffer from unequal bargaining power in a perfectly competitive labor market if the distribution of resources and rights is greatly skewed in favor of employers. I call this a case of unequal bargaining power "before the market," in contrast to the earlier case of inequality "within the market." 
Inequality of bargaining power before the market examines the wage/employment outcome with regard to alternative distributions/specifications of property rights and ownership. We again need a base-line in order to compare situations of equal and unequal bargaining power. For this purpose Commons (1934b, p. 683-4) invented the concept of reasonable value. Reasonable value is the community's conception of the legitimate, morally justifiable upper and lower bounds to the wage bargain, given the economic fundamentals existing at the time and the range of feasible/practical alternatives facing both parties (McIntyre and Ramstad 2002). Reasonable value is inherently subjective and contingent over time and place, yet it is also determinate in that a sovereign governmental body, such as the US Supreme Court (from which Commons derived this concept), has to determine the boundary lines between legitimate and illegitimate contract terms. To do this, the Court devised in the early twentieth century the doctrines of "reasonableness" and "conscienability." The idea is the Court refuses to set aside voluntarily negotiated contracts unless the negotiation process and/or terms are deemed unreasonable and/or unconscionable by prevailing community standards (Commons and Andrews 1936).

Inequality of bargaining power before the market, therefore, corresponds to wages and other conditions outside the range of reasonable value, with the connotation that these terms could only arise by a constellation of bargaining power that in current circumstances is sufficiently lopsided that it violates community standards of legitimacy. From this perspective, freedom of contract can be a cruel fiction that allows one side to impose onerous and exploitative terms on another. As before, in theory inequality of bargaining power before the market can favor either employer or employee; in practice, however, IE 
argues it usually favors employers and works against individual workers, particularly in early phases of economic development.

With regard to resources, for example, employers have far deeper pockets than workers who live paycheck to paycheck and can thus survive much longer if no deal is struck. Likewise, employers are less pressured to strike a deal since their revenue stream typically continues even if one job is vacant, while a worker's revenue stream typically ceases without that job. Also important, employers typically face more alternative job seekers than individual workers face alternative job openings (i.e., workers are usually on the "long side" of the labor market).

Rights are a second factor that determines bargaining power. IE contends that in all capitalist societies legal rights start out heavily skewed in favor of employers. One reason is that capital is typically scarce while labor is cheap and, therefore, societies give little regard to protecting labor; another is that employers have preponderant access to and influence in the legislative and judicial arenas (Commons 1934b, p. 673). Thus, while NL\&E theorizes that the evolution of the common law is driven by pressures of efficiency, IL\&E posits that in addition to efficiency pressures the common law also evolves from political contestation - that is, the process where social "outsiders" struggle to become "insiders" and, to the degree they are successful, judges re-interpret the common law to incorporate their interests (Deakin and Wilkinson 2005).

As seen in IE, many legal rules a century ago, and some today, regarding ownership and property rights create unequal bargaining power before the market (Adams 1886; Commons and Andrews 1936). One such example is employment-at-will. In any real world labor market the costs of employment-at-will fall disproportionately on workers, 
undercutting their bargaining power vis-à-vis the firm and thus shifting their labor supply curve to the right (with unequal bargaining power, their minimum supply price is reduced). Also relevant is immigration law. A legal rule that allows large immigration into the nation also shifts the labor supply curve to the right, lowering wages and conditions for workers. From a NE perspective, the new wage outcome is competitive and prima facie good for social welfare since efficiency is promoted when market prices adjust to reflect a change in relative factor scarcities. From an IE perspective, on the other hand, the same outcome, although nominally competitive, may well be in the bigger picture a socially inefficient and unjust outcome because it reduces the wages and conditions of labor below a reasonable or even long-run subsistence level (e.g., child labor, lack of health insurance). In fact, IE contends that what appears to be a competitive market outcome is in fact a case of institutional exploitation - the difference between a minimally reasonable wage and set of employment conditions and the actual level resulting from the skewed rules of the game (Taylor 1977).

Before moving on, it is useful to point out that employers are not the only or perhaps even major party using government to skew the rules of the game against the interests of workers. Consumers also have an incentive to do so (Webb and Webb 1897; Commons 1909). Consumers have dual interests to the degree that they not only buy goods but also sell labor. Nonetheless, IE surmises that their self-interest on balance tilts toward lower priced goods, given that lower prices of the $\mathrm{N}$ consumption goods in the economy improves every consumer's welfare but most forms of higher labor standards improve welfare for only a sub-group. If we look at a minimum wage, for example, most people work at companies that pay considerably above this level, so voting for political candidates 
who favor a minimum wage increase is likely to reduce their real income (via higher prices) without any compensating gain in wages. Examined this way, both consumers and firms have a shared interest in lower labor cost and shared interest in laws, regulations and an institutional infrastructure that promote such. A political economy perspective on labor markets suggests, therefore, that the erstwhile competitive labor market may well be in fact a disguised site of greatly unequal bargaining power.

\{Figure 2.3. IL\&E Perspective: Economic Effects of Labor Market Regulation\}

Involuntary unemployment and destructive competition

A second rationale for labor market regulation is labor market and macroeconomic stabilization. This goal also complements the employee protection and industrial democracy goals by shielding wages, working conditions and treatment from the downward drag exerted by excess labor supply in the aggregate market economy.

Commons asserted that chronic unemployment is the single greatest cause of labor problems and capitalism's greatest vulnerability (1934b, p. 804); the IL\&E case for labor market regulation rests, in turn, as much on the evils of unrestrained/excessive competition in labor markets as restricted competition. In this regard, the early institutionalists were "proto-Keynesians" in that they rejected Say's Law, emphasized the link between purchasing power and full employment, and rejected wage reductions as a method to eliminate excess labor supply (Kaufman 1997; Atkinson and Oleson 1998).

Neoclassical economists draw the demand and supply curve diagram and pick the equilibrium wage as the starting point for analysis of a labor law without mentioning one 
hugely important assumption -- that is, that the labor market is thereby presumed to be at a point of full-employment, indicated by an equality between labor demand and labor supply (with, in reality, some positive frictional unemployment). This presumption rests, in turn, on what is surely the most fundamental proposition in neoclassical economics: the idea that competitive markets are self-regulating and flexible prices rise or fall to bring the market back to a demand and supply equilibrium (Kniesner and Goldsmith 1987). Mainstream economics recognizes as amendments to the theory that many things ("frictions") can impede and interfere with this process, but nonetheless the assumption is that as a general description and central tendency the model of demand and supply and Adam Smith's invisible hand captures the reality of a market economy (Reder 1982; Lazear 2000). But IE explicitly denies both the Invisible Hand theorem and Say's Law that underlie this conclusion.

The first part of the IE argument is that involuntary unemployment is the normal or "default" condition in the aggregate labor market. This means that ordinarily the market economy is inside the production possibility frontier because it operates with underutilized labor resources. To get to this heterodox conclusion the only necessary change in NE assumptions is that economic agents are modeled as behavioral/social beings. The rest flows from this as a matter of logic.

According to competitive theory, persistent involuntary unemployment is a logical impossibility, per Reynold's statement that "all unemployment is by choice... it all boils down to a question of price" (1991, p. 176). IE argues, however, that workers cannot bid down wages even if they want because firms - particularly firms in "primary" labor markets (high wage, capital and knowledge intensive sectors) -- resist wage cuts. ${ }^{\text {vi }}$ The 
principal reason is the firms know that if they cut wages this also damages employee morale and work effort and, hence, they may end up with higher (not lower) labor cost. This happens if workers' productivity falls more than wage cost. This idea is a central lesson of efficiency wage theory (Solow 1990, discussed more below) and has found strong confirmation in recent laboratory experiments (Fehr and Falk 1999). Thus, if firms set and maintain above-market wages this leads to a semi-chronic condition of excess labor supply in the primary labor market - absent, of course, other forms of institutional intervention generally decried by NE theorists, such as activist government fiscal/monetary stabilization programs perhaps supplemented with an unemployment insurance program and/or government funded jobs program.

If the primary labor market is prone to chronic unemployment and jobs are in shortsupply at high wage firms, it is likely that a portion of the job seekers will shift to the lowwage secondary sector as they become more desperate for work, thus shifting the labor supply curve for low-pay workers rightward and further lowering their wage rate (Bulow and Summers 1986). When NE economists draw a demand and supply diagram and start the analysis of a labor market regulation at the "competitive" or "market" wage $\mathrm{W}_{1}$, they are thus engaging in two kinds of misrepresentation. The first is to assume that in primary labor markets there is a demand and supply balance when in fact jobs are rationed and labor is in excess supply. The second is to ignore the fact that in secondary labor markets this "competitive wage" has already been forced to a lower level by the crowding of people searching for work due to lack of jobs elsewhere. Again, therefore, we see that the NE labor market is the site of disguised unequal bargaining power that forces workers in the guise of 
freedom of contract to accept lower wages and conditions than would prevail in a truly competitive (full employment) labor market.

But the situation in low-wage labor markets can be much worse than this. According to NE theory, the solution to an excess supply of labor (unemployment) is a fall in the wage until labor demand and supply are brought into equality. This is why Reynolds states that involuntary unemployment is impossible -workers only have to lower their wage demand and they can "buy" a job. This is also one reason why NL\&E proponents criticize social insurance programs (e.g., insurance for unemployment, old age, disability); by giving people income when they're unemployed, their need to bid down wage rates to get gainful employment is alleviated. IE argues, however, that the NE logic is false and that in reality the process of wage reduction is likely to not only throw more people into destitution but also further worsen the unemployment situation. There are two steps in this argument.

The first is to show that wage reductions, even in a perfectly competitive economy, cannot cure unemployment. This proposition was embraced by Keynes (1936) and is the revolutionary part of his message. The reason advanced by Keynes is easily translated into institutionalist terms: the price mechanism fails because of a "missing institution;" that is, workers can not "buy" a job because the property right they have to trade -- a lower money wage -- is not commensurable with the property right employers want for their job opportunity -- a lower real wage (Chick 1983). In practical terms, as money wages are bid down, product prices soon follow and the real wage may actually increase rather than decrease - this is exactly what happened in the Great Depression. We have, therefore, a market/Invisible Hand coordination failure, necessitating supplementary or replacement 
coordination by an organization/Visible Hand, such as the state (Atkinson and Oleson 1998).

Given that money wage reductions cannot solve an aggregate unemployment problem, IE also goes the next step and demonstrates that wage reductions can actually lead to destabilizing/deflationary downward spiral in wages and prices, leading ultimately to capitalist catastrophe. They call this process destructive competition, also referred to today as a "race to the bottom" (Culbertson 1985; Kaufman 1997). It denies another central NE theorem: that "more competition in markets is always better than less" per the contention that perfect (unlimited) competition yields the Pareto-efficient outcome. It also opens up another avenue for employment regulation to do good rather than harm.

IE starts again with the notion of ownership and property. In a laissez-faire economy lacking any form of protective labor legislation (beyond ordinary contract and tort law) or social safety net, the worker's only income generating property is his or her labor. This asset earns zero, however, unless the worker can obtain a job from an employer. The key aspect of labor supply omitted from standard NE theory (e.g., Killingsworth 1983) is that workers have ongoing fixed costs of survival, including minimal expenditures for food, clothing, health, and housing. For household heads with non-working family members (e.g., wife and children), the fixed costs are several times larger. These costs are not to satisfy wants, but rather to cover basic human needs, and if unmet the human capital and physical selves of the agent and dependents depreciate and eventually perish (Prasch 1995; Kaufman 1999a). NE labor supply theory simply ignores fixed subsistence costs and instead dwells on the marginal cost of labor (the opportunity cost of giving up extra hour of leisure) -- in some cases augmented with a discussion of certain other kinds of fixed costs, 
such as child care and commuting. More remarkable is the advanced NE literature where, in general equilibrium theory of the Arrow-Debreu type, each agent supplying labor is assumed to have enough pre-market income to "ensure his own survival even if he is deprived of trade" [i.e., remains unemployed] (Geanakoplos 1987, p. 117). How workers get this income, if no welfare state exists, is never explained; the practical effect is to assume away the starkest reality of capitalism - that if people do not work they have no income to cover the fixed costs of survival.

Having set the stage, we can now watch destructive competition unfold. The first event is a significant decline in demand in the aggregate labor market. Workers in both primary and secondary labor markets lose their jobs and, with no other assets or government support, their income goes to zero. Their fixed costs continue, however, and as savings and other forms of support (charity and so on) are used up they become increasingly desperate to find work. The only solution, per NE theory, is to try to get work by underbidding someone else, or to have other family members enter the labor market. The latter effect -- the "added worker" effect -- makes the aggregate labor supply curve negatively sloped (Lester 1941; Prasch 2000; Dessing 2004). The reason is that with no other source of income support employees cannot exit the labor force as "discouraged workers," unless perhaps to survivalist farming or criminality, leaving the added worker effect dominant. Hence, the competition of the unemployed and new labor force entrants leads to downward movement of wages and other terms and conditions. In this story, Commons noted yet another source of increased labor supply during times of economic hardship that adds to the market glut - employed workers, desperate to keep their jobs, 
voluntarily work harder and also submit to speed-ups, thus allowing firms to further cut back on labor (1921, p. 269).

The NE theory presumes the fall in wage rates will eliminate the excess supply of labor and bring back full employment equilibrium, represented by a movement down given demand and supply curves until their intersection point. Institutionalists, however, deny this proposition. If the aggregate labor supply curve has a more elastic negative slope than the aggregate demand curve, which may plausibly be the case in recession/depression (again, with out a supportive welfare state), a fall in wages below the original equilibrium level will precipitate a destabilizing downward spiral of wages.

Further, the partial equilibrium flaw in the NE model again comes into play (Keynes' "fallacy of composition") because NE ignores the negative feedback effect that reduced wages have on household income and purchasing power. This problem is illustrated in panel (b) of Figure 2.3. For simplicity, I draw the aggregate supply curve as upward sloping, per convention. In this diagram, some negative spending shock causes a leftward shift of the aggregate labor demand curve, from $\mathrm{D}_{1}$ to $\mathrm{D}_{2}$ (point $A$ to $\mathrm{B}$ ). At the prevailing wage $\mathrm{W}_{1}$ there exists $\mathrm{L}_{1}-\mathrm{L}_{3}$ unemployed. To get jobs, they bid down the wage and in NE theory full employment is restored when the wage declines to $\mathrm{W}_{2}$ (a movement down the demand curve) and $\mathrm{D}_{2}$ equals $\mathrm{S}_{1}$. In Keynesian/IE theory, however, the decline in wages has a second effect (Chick 1983) -- it reduces household income and spending and leads to a leftward shift of product and labor demand curves, such as to D3 (point C). Thus, even with a positive sloped supply curve what develops is the potential for a dynamic nonequilibrating downward spiral of wages, employment and output (from point A to B to C and beyond), akin to a dog chasing its tail. From an IL\&E perspective, therefore, 
employment regulation has a positive role to play by short-circuiting this deflationary spiral - in effect keeping the otherwise unstable and unemployment-prone "free market" from shifting further inside the production possibility frontier.

With this scenario in mind, one can quickly appreciate that the New Deal labor program, embodied in the SSA, NLRA and FLSA, was conceived and implemented first and foremost as a macroeconomic stabilization measure (Mitchell 1986; Linder 1989; Kaufman 1996). The minimum wage, collective bargaining, unemployment insurance, old age insurance, overtime hours provision and child labor prohibition were intended to stabilize the economy and keep it closer to full employment through three channels: first, they put a floor under wages and labor conditions in labor markets and thus help shortcircuit the process of deflation and destructive competition; second, they add to household income and support spending and aggregate demand; and, third, they create automatic stabilizers that reduce cyclical volatility of spending. To an important degree these regulatory programs complement Keynesian aggregate demand management and weakening them in the name of labor market deregulation (e.g., cutting back unemployment insurance) only exacerbates the instability of the economy.

On the other hand, hallmark IE principles are balance and positive freedom and, with these in mind, proponents of employment regulation must also be careful not to overregulate labor markets; likewise, they must recalibrate employment regulation in light of evolutionary changes in society and the economy. Most certainly, IL\&E is not a one-way street to ever greater employment regulation.

A case in point concerns the role of unemployment. Due to the success of Keynesian-inspired countercyclical fiscal and monetary policies (and various structural 
shifts), post-World War II labor markets have operated closer to full employment. Part of the rationale for the full panoply of New Deal labor laws was to protect employment conditions from the corrosive effect of the mass unemployment of the 1930s; evidently, this same level of protection and regulation may be excessive in the modern era of global competition, supply-side growth and closer-to- full employment labor markets. In particular, widespread collective bargaining may shift from being (on net) "monopsony reducing" to "monopoly creating," with greater negative effects on productivity, inflation and competitiveness (Hirsch 2007; Kaufman 2007d). Yet even here there are countervailing arguments typically omitted from the debate. But this thought moves us to the next section.

\section{Efficiency and growth}

The third IL\&E rationale for employment regulation is that it promotes greater economic efficiency and growth. The hallmark of the NE criticism of regulation is that it distorts the price system and leads to resource misallocation and economic inefficiency. This is one side of the story, and certainly one that IE admits has some truth. But IE points out an entirely different and more positive side which NE proponents most often fail to mention. That is, for several reasons outlined below employment regulation may not only promote efficiency and help keep the economy on the production possibility frontier but also encourage the productivity growth that shifts the frontier rightward over time.

First to consider is another variant of IE's "balance" idea. As already noted, the NE presumption is that more competition is better than less; the presumption of IE is that beyond some level competition becomes excessive and retards efficiency. We have already 
encountered this idea with the doctrine of destructive competition; here enters a second and perhaps even more compelling argument.

Secure property rights are crucial to the success of a market economy and one of the core functions of government in the neoclassical/neoliberal paradigm is to protect and enforce these rights. Who will invest in productive enterprise, after all, if one's property can be easily confiscated without compensation? An insight of IE is that a competitive labor market puts the worker exactly in this situation, leading to under-investment in work effort and human capital (Commons 1921).

The neoclassical conception of property in a market exchange context is a “commodity," typically some physical/measurable good or service. Perfect competition presumes, in turn, that all aspects of a commodity's property rights are well-defined and priced. In Legal Foundations of Capitalism (1924), Commons describes in considerable detail the evolution of the legal conception of property. He describes that a great transformation occurred in the late $19^{\text {th }}$ century when the US Supreme Court ruled that property is not only the physical item itself (use value) but also the exchange value of the item. This distinction arose, among other places, in labor disputes where the Court granted firms an injunction against striking employees, not because they were damaging the employer's physical property but because they damaged the market value of the property by keeping away customers and preventing the shipment of goods.

This expanded notion of property opens up a Pandora's Box for neoclassical theory, however. Perfectly secure property rights are a cornerstone of the competitive model, but if secure property rights are taken to mean legally guaranteed exchange values, then prices/wages can never deviate from some original equilibrium level (at least without 
offsetting compensation). That is, a change in demand and supply leads to a change in the value of property and, for the parties who price works against, part of their property is "stolen" by the market just as much as if a thief trespassed and carried it away. Absolute security of property, therefore, can only be attained by rigidly fixed prices, no doubt much to the harm of allocative efficiency.

On the other hand, if property rights are taken to mean only secure use values, then large changes in demand and supply and market price can dramatically alter the exchange value of property. NE labels this a "pecuniary externality," but concludes it does not interfere with attainment of efficiency (Cornes and Sandler 1996). IE suggests, however, that pecuniary externalities, and more generally the much-touted "flexibility" of competitive markets, may actually reduce efficiency in an economy of real people. This proposition rests on the observation that competitive markets (in any real form) create large amounts of insecurity for economic agents and hence, beyond some interior point, greater insecurity makes workers less productive (an inverse $U$ relationship). There are two reasons for this.

First, employment insecurity -- the opposite of entitlement -- up to some point is a positive/constructive source of motivation that causes people to work hard and do what is best for the long-run interests of the firm; beyond some point, however, greater insecurity reduces work motivation and performance by creating dysfunctional levels of stress, impaired decision-making and attention (bounded rationality), constant job search and unduly short time horizons (Polanyi 1944; Kaufman 1999b). ${ }^{\text {vii }}$

Second, it is widely recognized that workers perceive they develop a stronger property right in their jobs as they accumulate additional years of tenure with the firm 
("sweat equity"), even though of course the courts and legislatures have generally refused to legally recognize such a right (Fogel 1982). When firms cut wages and benefits or layoff people, as would routinely happen in a competitive market, workers instinctively regard this as tantamount to theft of part of their property right in the job, leading them to react/retaliate in a variety of ways that erode efficiency (Perlman 1928; Polanyi 1944). Examples include reduced work effort, greater absenteeism and calling in the union organizer. Thus, measures that reduce excessive wage/employment insecurity -- without going to the other extreme of a completely rigid wage/employment system -- promote efficiency. This idea is one of the foundation stones for the modern welfare state and labor law is the vehicle for implementing it (Moss 1996).

Much the same idea applies to investment in human capital. An NE indictment of any form of labor market regulation that puts a floor on wages is that it reduces firms' willingness to provide general on-the-job training since workers can no longer offer to work for a lower wage to compensate firms for the cost of the training. But, as in all these matters, there is another side to the story (Acemoglu and Pischke 1999). Rarely asked are the following questions: Will firms invest in specific job training? Will such training be attractive to workers if the value of this asset is at great risk from lay-offs due to shifts in demand and supply in laissez-faire labor markets? Probably not, just as Galbraith (1967) argues that firms are unwilling to invest billions needed to finance new products and plants without stable market conditions. The same logic applies to investment in internal labor markets and progressive human resource management practices, even though both may be profitable over the long-run and quite socially desirable. We again see that the optimal level of market competition is not the maximum but some intermediate point, leading to the 
heretical conclusion that a market economy with some degree of imperfect competition and employment regulation will outperform its competitive/laissez-faire rival.

Labor market regulation and mandates may promote greater efficiency and growth through several other channels. All involve some aspect of human agency and incomplete contracts.

A well-known example is through efficiency wages, a modern development but one that goes back to Adam Smith (Smith 1776/1937, p. 81; Akerlof and Yellen 1990; Solow 1990). A key assumption of standard microeconomic price theory is that the worker's marginal product (increment to output) is independent of the wage rate. This is assured by modeling labor as an inanimate commodity so the marginal product is a technologically determined datum. An increase in the wage in a competitive market from a union or minimum wage law unambiguously moves firms up their labor demand curves and reduces employment. But if labor is embodied in human beings, and positive transaction cost creates incomplete contracts, then a higher wage may lead to an offsetting increase in the marginal product to the extent it elicits more labor supply (work effort, on-time attendance, etc.) from employees (Ippolito 2003). This result may occur on a variety of grounds, such as fairness or fear of termination. Whatever the case, over a modest range it is quite possible that the effective labor demand curve is vertical or even positive, implying that an employment regulation may create no dis-employment effect or efficiency loss (Perlman 1969, p. 50-55).

A similar conclusion concerns the IE "shock effect" argument. Instititutionalist Sumner Slichter (1931) argued that collective bargaining and minimum wages might not produce a negative employment effect because the increase in labor cost motivates (shocks) 
management into tightening up on other elements of cost in order to maintain profitability. NE economists (e.g., Stigler 1976) dismiss this argument as ad hoc or lacking empirical evidence. IE, however, provides a logical account for the shock effect. Assuming economic agents are human beings, this leads to bounded rationality, positive transaction cost and volitional effort supply. The first casualty is the NE hypothesis of cost minimization/profit maximization. Positive transaction cost and incomplete contracts opens the door for the principle-agent problem in firms. The interest of the owners is maximum profit, but the interest of the salaried managers is their own utility maximization - a function of firm profits (required to keep their jobs) but also other things that decrease profit, such as skyhigh executive salaries and growth for growth's sake (e.g., through mergers and acquisitions). Institutionalists, such as Berle and Means (1932), have labeled this the "separation of ownership and control" and note that it can lead to "satisficing" behavior with regard to cost and profits (Simon 1982; Kaufman 1999b, Altman 2001). Satisficing behavior, in conjunction with a minimum necessary level of profits, leads management to tolerate organizational slack, above-minimum costs and in general some degree of inefficiency. A rise in labor cost from a labor law or mandate does not, therefore, necessarily translate into any decrease in employment, since the managers may well be able to find equivalent cost savings in other areas, including their own effort supply and multimillion dollar compensation.

A third efficiency-enhancing channel deserving mention is that employment regulation not only protects workers but also protects "high road" employers who make long-term investments in human capital, physical capital and R\&D. Research shows that productivity is higher at firms using a "high performance work system" (HPWS) composed 
of self-managed work teams, job security provisions, extensive training, employee involvement methods, and formal dispute resolution programs (Black and Lynch 2001). An HPWS requires, however, large upfront investment cost, just as does building new state-ofthe-art plants or conducting leading-edge $R \& D$. These kinds of investments are crucial for long run growth but may be seriously impeded by the instability and hyper short-term competition found in competitive markets (Cappelli, et. al., 1997). Employment regulation can protect and encourage new forms of work organization, such as HPWS, by putting a floor under competition so firms skimping on wages and labor conditions cannot gain an undue competitive edge and drive these firms out of business.

Last but not least, we come to the link between efficiency and fairness. This link was already touched upon with regard to efficiency wages but has a much broader and compelling role to play. An implication of the NE fundamental welfare theorems is that attainment of Pareto efficiency in a competitive economy is independent of fairness in endowments and outcomes (Stiglitz 2000). IE denies this proposition at both a micro and macro level.

At a micro level, commodities do not care if they receive a high or low price and have no conception of fair treatment. People do, however. Research in behavioral and experimental economics systematically shows that when procedural and distributive norms of fairness in the workplace are violated workers retaliate by reducing work effort, cooperation and organizational citizenship behavior, thus exacting a reciprocal "price" in the form of reduced profit and efficiency (Falk, Fehr and Fischbacher 2003; Schmid 2004).

At a macro level, fairness also promotes efficiency and growth (Kitson, Martin and Wilkinson 2000). Societies that have a more balanced income distribution (at least up to a 
point) show higher growth rates (Gobben, Rayp and Van de Gaer 2007). A reason is that when all parts of a society feel they are sharing equitably in the fruits of productive enterprise they also feel more committed to and respectful of the enterprise. This sense of shared gain and social solidarity helps maintain and expand both a firm's and nation's single most productive asset - a cohesive, cooperative and lawful institutional order. Without such an institutional order, and the sense of inclusion and fair treatment it rests on, organizations and societies fall into the non-cooperative trap of the Prisoner's Dilemma game (Miller 1991). Labor market regulation and employment mandates are one solution to maintaining cooperation and social justice -- and avoiding industrial conflict and adversarial employment relations.

Externalities and social costs of labor

We now come to the fourth rationale advanced by IE economists for labor market regulation and employment mandates - labor market externalities and social costs of labor. As earlier indicated, NE recognizes that externalities provide a public interest rationale for employment regulation; the difference between NE and IE on this matter is, therefore, over the extent and severity of externalities. In particular, IE maintains externalities are more widespread and severe than NE generally assumes.

An externality arises any time one or more dimensions of a good or service are not fully covered in a complete contract, thus allowing part of the benefits or costs to "leakout" and affect third parties. When this happens, there develops a divergence between the private benefit/cost realized by the buyer and seller and the social (or total) benefit/cost 
realized by the buyer, seller and all affected third parties (Addison and Hirsch 1997). Since buyers and sellers make decisions based on private benefits/costs, this divergence necessarily leads to incorrect decisions, false price signals in the market, and economic inefficiency from misallocated resources and inequity from misplaced or unanticipated gains/losses in exchange.

Although externalities affect both sides in the labor market, the ILE presumption is that they have a greater adverse impact on workers. In particular, for reasons described below employers can often shift private production cost on to workers, their families and other third parties as a form of social cost (Blum 1956; Stabile 1993a, 1993b; Prasch 2005). The extent of this "social cost" becomes even larger when the notion of property rights is extended from commercial goods and services to fundamental human and social rights at work, given that these rights (e.g., freedom of speech and association) have no market price and therefore are not factored into firms' production plans and human resource practices (Sunstein 2004; Deakin and Wilkinson 2005). A function of employment regulation, therefore, is to prevent this cost shifting or provide injured parties with compensation for it.

To demonstrate, I give examples of how several different forms of employment regulation may help solve a social cost problem, including a legislated minimum wage, universal health insurance, and a wage subsidy.

A serious gap in NE labor supply theory, as already noted, is the focus on marginal cost and neglect of most elements of fixed cost, particularly individual and family subsistence. However, in the classical economics that preceded NE labor's subsistence wage was a central focus of attention. Adam Smith noted, for example, that "A man must always live by his work, and his wages must be at least sufficient to maintain him" 
(1776/1937, p. 67). This insight was later developed by the Sidney and Beatrice Webb and

John M. Clark into a social rationale a "national minimum" in terms of wages, earnings and benefits (Webb and Webb 1897; Clark 1923). The idea is explained by Sidney Webb:

The continued efficiency of a nation's industry obviously depends on the continuance of its citizens in health and strength. For an industry to be selfsupporting, it must, therefore, maintain its full establishment of workers unimpaired in numbers and vigor, [and] with a sufficient number of children to fill all vacancies caused by death or superannuation. If the employers in a particular trade are able to take such advantage of the necessities of their workpeople as to hire them for wages actually insufficient to provide enough food, clothing, and shelter to maintain them permanently in average health; if they are able to work them for hours so long as to deprive them of adequate rest and recreation; or if the can subject them to conditions so dangerous or insanitary as positively to shorten their lives, that trade is clearly obtaining a supply of labor force which it does not pay for... he [the employer] is clearly receiving a subsidy or bounty .... [and is] economically parasitic (1912, p. 986, 987).

The idea is that the wage paid workers must cover not only the opportunity cost of leisure but also the maintenance and depreciation of their human capital, otherwise private production cost understates social production cost. This means that the wage must cover items such as minimal necessary health expenditure, minimal retirement income, minimal income support during periods of unemployment, and minimal income for dependent children (so the nation has a future workforce). Firms, however, may be able, because of market imperfections and incomplete contracts, to partially or completely avoid paying these costs, which in effect also shields consumers from these costs through higher product prices. Instead, the costs are shifted to the workers themselves, their families, local communities, or the nation at large. For example, firms with market power may be able to 
obtain employees and yet not pay health insurance, while other firms may opportunistically renege on pension payments by firing workers when they get closer to retirement age. Consumers and firms are, in Webb's term, "parasitic" in that they enjoy lower prices and more material abundance at workers' expense - particularly the expense of low-wage workers who often work in unsafe jobs, have the least financial ability to withstand illhealth, and have the least income for and accessibility to alternative suppliers of health care.

A shifting of social labor cost is also facilitated by a second factor. This is a large supply of labor in the market. Even in a perfectly competitive labor market, the wage may not cover the subsistence cost of labor. For example, a huge number of firms will flood the market with product, cause the price to fall until enough firms "die," which constricts supply and restores profit to a normal ("subsistence") level. The same process works in labor markets. Assume, for example, large scale immigration into the nation. To balance supply and demand, the wage may have to fall so far that it does not cover the minimum subsistence costs of labor. The parallel market solution is that some workers need to "go out of business" so that the labor supply shrinks until wages again cover minimum fixed and variable labor cost. This process may happen in a variety of ways: for example, workers may withdraw from the labor market and maintain themselves through crime or in the underground economy; they may become homeless and beg for food and live in community shelters; or they may go out of business through sickness and starvation - as millions of workers and their families do in various parts of the world today. Of course, if workers had a legal/human right to the social wage the externality/social cost problem would disappear. Commons proposed exactly this a century ago - a legislated "right to 
work" guarantee or equivalent amount of income -- but was denounced as a proto-Socialist (Kaufman 2003). It is, however, the logical step to making the competitive labor market even more "perfect" by filling in a missing property right and eliminating an externality (Standing, 2004). Absent this step, a distinctly second-best - but better than nothing solution is a minimum wage, earned income tax credit, or collective bargaining.

Firms may also shift labor costs in a variety of other ways. A classic example is costs of workplace injury and illness (Burton and Chelius 1997). Production inherently involves a risk for workers of injury, illness and sometimes death. In theory, these costs are part of production cost and should be fully borne by the firm and then, ultimately, by consumers in the form of higher product prices. In a perfect labor market, the costs of accident and illness are fully incorporated into higher wages (as a compensating differential) and are thus passed through to firms and consumers; in an imperfect labor market, however, firms (and hence consumers) can successfully shift these costs to others. For example, if labor markets have involuntary unemployment then firms face an excess supply of labor and may not have to pay compensating wage differentials; alternatively, firms with labor market power may underpay employees partly by under-investing in workplace safety and health practices. A workmen's compensation law, therefore, by imposing an injury tax on firms may move the labor market closer to a competitive equilibrium by making private cost come closer to social cost. Similar considerations may affect other health issues for employees, such as maternity leave, and here some form of mandate could also accomplish the same end.

These arguments are demonstrated in panel (c) of Figure 2.3. When NE economists analyze the economic effects of a labor law, they draw a diagram with the demand and 
supply lines, $\mathrm{D}_{1}$ and $\mathrm{S}_{1}$, and label $\mathrm{W}_{1}$ the "competitive" wage (point $\mathrm{A}$ ). But in doing so they omit from the diagram one crucial consideration: The social wage that covers the full cost of the labor input, including dependent family members if labor is to reproduce itself. The social wage, assumed here to be $\mathrm{W}_{2}$, may be above, equal to, or below the prevailing market wage; the exact relationship is ultimately an empirical issue. I assume here, for purposes of exposition, that the market wage is below the social wage.

We may call the market wage $\mathrm{W}_{1}$ a pseudo competitive wage-pseudo because, first, it is an illusion obtained only by omitting consideration of the full social cost of labour and, second, because it purports to yield an efficient resource allocation when in fact it yields an inefficient allocation (as with any externality). In panel (c), the difference $\mathrm{W}_{2}-\mathrm{W}_{1}$ represents the per unit social tax on labour and social subsidy to capital and consumers.

Given this market failure, Coase (1960: 18) argues, "the problem is one of choosing the appropriate social arrangements for dealing with harmful effects." A variety of alternatives are available. Consider, first, a legally mandated minimum wage. The idea is to set the minimum wage at the level of the social wage $\mathrm{W}_{2}$, thus creating a wage floor that (just) covers labour's minimum fixed and variable cost. The wage floor is depicted in panel (c) of Figure 1 by the solid horizontal line at $\mathrm{W}_{2}$. To the degree social wages vary across workforce groups (e.g., men and women), a better but more administratively difficult approach is to set different wage floors.

Special notice should be given in this situation to the employment and unemployment effects of labor law. In reaction to the imposition of the wage floor $\mathrm{W}_{2}$, employment declines from $L_{1}$ to $L_{2}$ (point $A$ to $B$ ) -- exactly the negative employment effect the critics of minimum wage laws highlight. But note that this employment decline, 
as judged by the theory of orthodox economics, should be welcomed because it eliminates inefficient use of the nation's labor resources caused by a market imperfection (an externality). Critics, nonetheless, may assert it is socially misguided to destroy these $\mathrm{L}_{1}-\mathrm{L}_{2}$ jobs when they are held by low-wage workers who presumably need them and, further, voluntarily accepted them. After all, don't all sides gain from trade? The answer is "no": On efficiency grounds these outcomes are harmful to both workers and society if the market wage is less than the social wage, while on normative grounds they represent retrogression to inhumane labor conditions that advanced societies have long ago repudiated. Similarly, in reaction to the minimum wage unemployment increases to $\mathrm{L}_{3}-\mathrm{L}_{2}$ amount (point $\mathrm{C}$ to $\mathrm{B}$ ), but this is a social virtue to the extent making work more rewarding draws in $\mathrm{L}_{3}-\mathrm{L}_{1}$ new job seekers who were otherwise supporting themselves by crime or activities in the underground economy.

The social cost problem outlined above may be solved by a minimum wage law or a wage increase bargained by a trade union. But better solutions may also be available. One is to directly eliminate the social cost problem, say through universal health insurance. A second is to shift the labor demand curve to the right through some type of wage or job subsidy to employers (thus closing the social cost gap but increasing employment). Yet a third is an income supplement for workers, such as the Earned Income Tax Credit program.

A central tenet of IL\&E is that free labour markets - despite their many admitted virtues - will lead to numerous instances of inefficiency, injustice, and shortfalls in human wellbeing. The social cost problem is one example. The social cost problem also illustrates another feature of IL\&E - a dedication to finding pragmatic, workable solutions to employment problems in the here and now. If the superior solution (e.g., universal health 
care) is not readily attainable, then IL\&E proponents believe a second-best solution (e.g., a minimum wage) is preferable to no policy at all. Commons' student John Fitch well summarizes the IL\&E philosophy on this matter: "It is not legislation as such we desire, but social advance" (1927, p.243).

\section{Conclusion}

The theme of this chapter is that there are (at least) two sides to every debate and the debate over the pros and cons of employment regulation is no exception. In this spirit, I have endeavored to present in a fair and balanced way both sides to the employment regulation debate -- the "anti-regulation" NL\&E movement and the "pro-regulation" IL\&E movement. These labels, of course, are generalizations that hide a wide spectrum of individual opinion and, as I have hopefully depicted, both sides capture important elements of truth.

The "bottom line" conclusion from this analysis is that whether one tends toward a NL\&E or IL\&E perspective turns on several fundamental considerations. One is the competitive nature of labor markets and, in particular, the degree to which they locate toward the highly competitive versus highly non-competitive pole; a second is the way firms are modeled (production functions or governance systems); a third is the relative weight given to different interests in society (e.g., consumers' versus workers' interests); a fourth is the degree to which labor is treated as one of $\mathrm{N}$ exchangeable commodities versus a unique "human factor" endowed with certain inalienable rights; and a fifth is the social, cultural and historical background that conditions each person's viewpoint (preferences) on these matters. 
Seen in this light, there is no single right answer to the question "what is the optimal amount of employment regulation?" since the answer is crucially contingent on these assumptions and how they are specified in theoretical models. In the end, theory can guide the discussion and inform our priors but the final verdict inevitably rests on the weight of empirical evidence and each person's normative judgment about whose interests are to count and the type of world we want to live in. Not even appeal to efficiency can reveal a value free and determinate outcome, given that efficiency itself cannot be calculated until we specify whose preferences (interests) are being maximized - the antecedent issue that lies at the very heart of law and politics. 


\section{Diagrams}

(a) Covered Sector

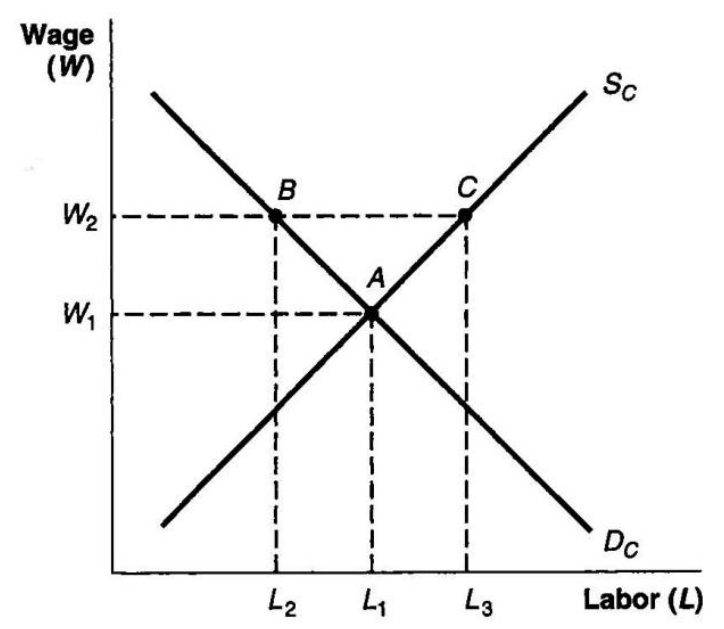

(b) Uncovered Sector

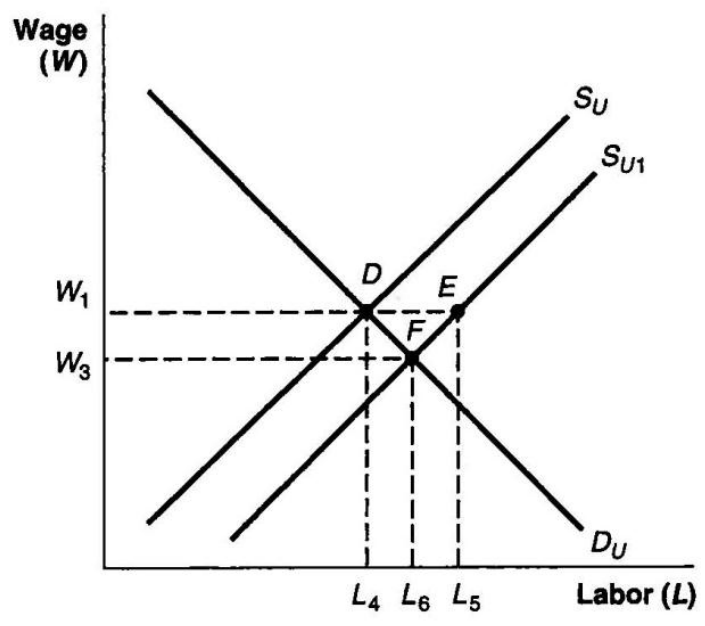

Figure 2.1. NL\&E Perspective: Economic Effects of Labor Market Regulation 


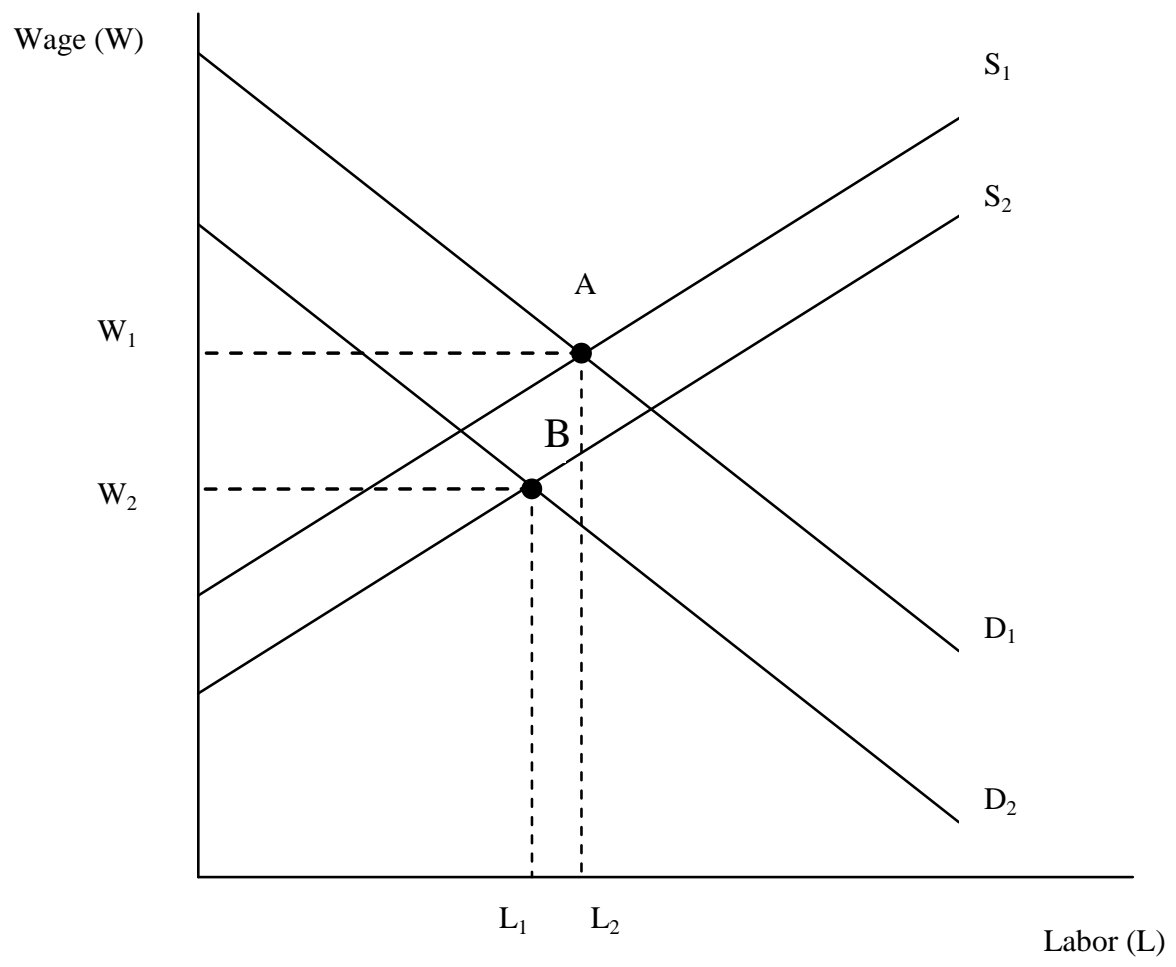

Figure 2.2. NL\&E Perspective: Economic Effects of an Employment Mandate 


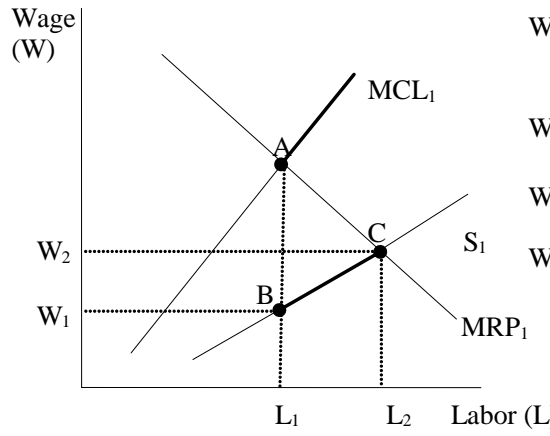

(1) Imperfect Labor Market

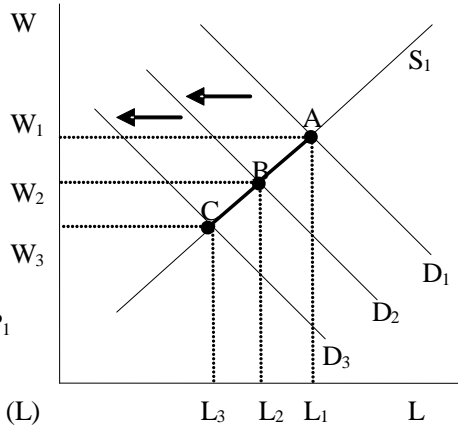

(2) Unemployment and Destructive Competition

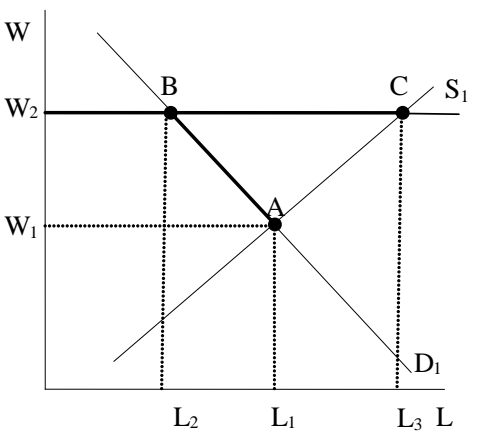

(3) Social Costs of Labor

Figure 2.3. IL\&E Perspective: Economic Effects of Labor Market Regulation 


\section{References}

Acemoglu, Daron and Jörn-Steffen Pischke (1999), 'Beyond Becker: Training in Imperfect Labour Markets,' Economic Journal, 109 (February), F112-F142.

Adams, Henry (1887), 'Relation of the State to Industrial Action.' reprinted in Joseph Dorfman (ed.) (1969), Two Essays by Henry Carter Adams, New York: Kelley, pp. 59-133.

Adams, Henry (1897), 'Economics and Jurisprudence’ reprinted in Joseph Dorfman (ed.) (1969), Two Essays by Henry Carter Adams, New York: Kelley, pp. 137-75.

Addison, John and Barry Hirsch (1997), 'The Economic Effects of Employment Regulation: What are the Limits?' in B. Kaufman (ed.), Government Regulation of the Employment Relationship, Madison: Industrial Relations Research Association, 125-78.

Akerlof, George and Janet Yellen (1990), 'The Fair Wage-Effort Hypothesis and Unemployment,' Quarterly Journal of Economics, 105 (2), 255-83.

Altman, Morris (2001), Worker Satisfaction and Economic Performance, New York: M.E. Sharpe.

Arthurs, Harry (2002), 'National Traditions in Labor Law Scholarship: The Canadian Case,' Comparative Labor Law \& Policy Journal, 23 (3), 645-78.

Atkinson, Glen and Theodore Oleson Jr. (1998), 'Commons and Keynes: Their Assault on Laissez-Faire,' Journal of Economic Issues, 32 (December), 1019-30.

Baird, Charles (2000), 'Unions and Antitrust,' Journal of Labor Research, 21 (4), 585-600. 
Becker, Gary (1962), 'Irrational Behavior and Economic Theory,' Journal of Political Economy, 70 (February): 1-13.

Berle, Adolf and Gardiner Means (1932), The Modern Corporation and Private Property, New York: Macmillan.

Bernstein, Michael (2001), A Perilous Progress: Economists and Public Purpose in Twentieth-Century America, Princeton: Princeton University Press.

Bhaskar, V. and T. To (1999), 'Minimum Wages for Ronald McDonald Monopsonies: A Theory of Monopsonistic Competition,' Economic Journal, 109 (April), 190-203.

Birk, R. (2002), 'Labor Law Scholarship in France, Germany and Italy: Some Remarks on a Difficult Question,' Comparative Labor Law \& Policy Journal, 23 (3), 679-700.

Block, R.ichard, Peter Berg and Dale Belman (2004), 'The Economic Dimension of the Employment Relationship,' in Jackie Coyle-Shapiro, et al. (eds), The Employment Relationship: Examining Psychological and Contextual Perspectives, Oxford: Oxford University Press, pp. 94-118.

Blum, Fred (1956), 'The Social and Economic Implications of the Fair Labor Standard Act: An Interpretation in Terms of Social Cost,' Proceedings of the Ninth Annual Meeting of the Industrial Relations Research Association, Madison: IRRA, pp. 16783.

Booth, Alison (1995), The Economics of Trade Unions, New York: Cambridge University Press.

Boulding, Kenneth (1957), 'A New Look at Institutionalism,' American Economic Review, 47 (May), 1-12. 
Barro, Robert (1997), Determinants of Economic Growth: A Cross-Country Study

Cambridge: MIT.

Black, Sandra and Lisa Lynch (2001), 'How to Compete: The Impact of Workplace Practices and Information Technology on Productivity,' Review of Economics and Statistics, 83 (3), 434-45.

Blanpain, Roger (1999), European Labour Law, $6^{\text {th }}$ ed., Boston: Kluwer Law International. Bowles, Samuel and Herbert Gintis (1993), 'The Revenge of Homo Economicus: Contested Exchange and the Revival of Political Economy,' Journal of Economic Perspectives, 7 (1), 83-102.

Budd, John (2004), Employment with a Human Face: Balancing Efficiency, Equity and Voice, Ithaca: Cornell University Press.

Bulow, Jeremy and Lawrence Summers (1986), 'A Theory of Dual Labor Markets with Application to Industrial Policy, Discrimination, and Keynesian Unemployment,' Journal of Labor Economics, 4 (July, Part 1), 376-414.

Burton, John and James Chelius (1997), 'Workplace Safety and Health Regulations: Rationale and Results,' in B. Kaufman (ed.), Government Regulation of the Employment Relationship, Madison: Industrial Relations Research Association, pp. 253-94.

Butler, Henry and Keith Chauvin (1999), 'Economic Analysis of Labor Markets: A Framework for Analyzing Employment Law Issues,' Kansas Journal of Law \& Public Policy, 8 (3), 1-21.

Cahuc, Pierre and Zylberberg, Andre (2004), Labour Economics, Cambridge, MIT Press. 
Campbell, Thomas (1986), 'Labor Law and Economics,' Stanford Law Review, 38 (4), 9911064.

Cappelli, Peter, et al. (eds) (1997), Change at Work, London: Oxford University Press.

Card, David and Alan Krueger (1995), Myth and Measurement: The New Economics of the Minimum Wage, Princeton: Princeton University Press.

Chick, Victoria (1983), Macroeconomics After Keynes: A Reconsideration of the General Theory, Cambridge: MIT Press.

Clark, John B (1899), The Distribution of Wealth, New York: Macmillan.

Clark, John M. (1923), Studies in the Economics of Overhead Costs, Chicago: University of Chicago Press.

Coase, Ronald (1937), 'The Nature of the Firm,' Economica, 4 (November), 386-405.

Coase, Ronald (1960), 'The Problem of Social Cost,' Journal of Law and Economics, 3 (1), $1-44$.

Coase, Ronald (1988), The Firm, the Market, and the Law, Chicago: University of Chicago Press.

Coase, Ronald (1992), 'The Institutional Structure of Production,' American Economic Review, 82 (June), 713-19.

Collins, Hugh (2000), 'Justifications and Techniques of Legal Regulation of the Employment Relationship,' in Hugh Collins, Paul Davies and Roger Rideout (eds), Legal Regulation of the Employment Relationship, London: Kluwer Law International, pp. 3-27.

Commission on the Future of Worker-Management Relations (2004), Fact-Finding Report, Washington: US Department of Labor and US Department of Commerce. 
Commons, John (1909), ‘American Shoemakers, 1648-1895,' Quarterly Journal of Economics, 24 (November), 39-83.

Commons, John (1921), Industrial Government, New York: Macmillan.

Commons, John (1924), Legal Foundations of Capitalism, New York: Macmillan.

Commons, John (1925), 'Law and Economics,' Yale Law Review 34 (4), 371-82.

Commons, John (1934a), Myself, Madison: University of Wisconsin Press.

Commons, John (1934b), Institutional Economics: Its Place in Political Economy, New York: Macmillan.

Commons, John (1950), The Economics of Collective Action, Madison: University of Wisconsin Press.

Cook, Maria (2006), The Politics of Labor Reform in Latin America, College Station: Penn State Press.

Cornes, Richard and Todd Sandler (1996), The Theory of Externalities, Public Goods, and Club Goods, New York: Cambridge University Press.

Culbertson, John (1985), Competition: Constructive and Destructive, Madison: $21^{\text {st }}$ Century Press.

Dau-Schmidt, Kenneth (1992), 'A Bargaining Analysis of American Labor Law and the Search for Industrial Peace,' Michigan Law Review, 91 (3), 419-514.

Davies, Paul and Mark Freedland (2000), 'Employees, Workers, and the Autonomy of Labour Law,' in Hugh Collins, Paul Davies and Roger Rideout (eds), Legal Regulation of the Employment Relationship, London: Kluwer Law International, pp. 267-86. 
Davies, Paul and Mark Freedland (2002), 'National Styles in Labor Law Scholarship: The United Kingdom,' Comparative Labor Law \& Policy Journal, 23 (3), 765-88.

Deakin, Simon and Frank Wilkinson (2000), 'Labour Law and Economic Theory: A Reappraisal,' in Hugh Collins, Paul Davies and Roger Rideout (eds), Legal Regulation of the Employment Relationship, London: Kluwer Law International, pp. 29-62.

Deakin, Simon and Frank Wilkinson (2005), The Law of the Labour Market, New York: Oxford University Press.

Dessing, Maryke (2004), 'Implications for Minimum-Wage Policies of an S Shaped LaborSupply Curve,' Journal of Economic Behavior and Organization, 53 (4), 543-68.

Donohue, John III (2007), Economics of Labor and Employment Law, vols 1 \& 2, Northampton, MA: Edward Elgar.

Donohue, John III and Peter Siegelman (1991), 'The Changing Nature of Employment Discrimination Litigation,' Stanford Law Review, 43 (5), 983-1034.

Dorfman, Joseph (1949), The Economic Mind in American Civilization, vol. 3, New York: Viking.

Douglas, Paul (1938), “The Economic Theory of Wage Regulation,” University of Chicago Law Review, 5 (2), 184-218.

Dow, Gregory (1997), ‘The New Institutional Economics and Employment Regulation,' in B. Kaufman (ed.), Government Regulation of the Employment Relationship, Madison: Industrial Relations Research Association, pp. 57-90.

Ehrenberg, Ronald and Robert Smith (2007), Modern Labor Economics, $9^{\text {th }}$ ed., Boston: Pearson. 
Epstein, Richard (1983), ‘A Common Law for Labor Relations: A Critique of the New Deal Labor Legislation,' Yale Law Journal, 92 (8), 1357-1408.

Epstein, Richard (1984), 'In Defense of the Contract at Will,' University of Chicago Law Review, 51 (4), 947-82.

Epstein, Richard and Jeffrey Paul (1985), Labor Law and the Employment Market, New Brunswick: Transaction Press.

Erickson, Christopher and Daniel J.B. Mitchell (2008), 'Monopsony as a Metaphor for the Emerging Post-Union Labour Market,' International Labour Review, 146 (3-4), 163-87.

Estlund, Cynthia (2006), 'The Death of Labor Law?' Annual Review of Law \& Social Science, 2, 105-23.

Falk, Armin, Ernst Fehr and Urs Fischbacher (2003), 'On the Nature of Fair Behavior,' Economic Inquiry, 41 (1), 20-26.

Farber, Daniel (2001), 'Toward a New Legal Realism,' University of Chicago Law Review, 68 (1), 279-303.

Fehr, Ernst and Armin Falk (1999), 'Wage Rigidity in a Competitive Incomplete Contract Market,' Journal of Political Economy, 107 (February), 106-34.

Fitch, John (1927), 'An Oasis That is Full of Promise,' American Labor Legislation Review, 17 (3), 242-43.

Fogel, Walter (1982), Job Equity and Other Studies in Industrial Relations: Essays in Honor of Frederic Meyers, Los Angeles: Institute of Industrial Relations, UCLA.

Freeman, Richard and James Medoff (1984), What Do Unions Do? New York: Basic Books. 
Fried, Barbara (1998), The Progressive Assault on Laissez-Faire: Robert Hale and the First Law and Economics Movement, Cambridge: Harvard University Press.

Friedman, Milton (1962), Capitalism and Freedom, Chicago: University of Chicago Press.

Friedman, Milton and Rose Friedman (1980), Free to Choose: A Personal Statement, New York: Harcourt Brace Jovanovich.

Furubotn, Erik and Rudolp Richter (1997), Institutions and Economic Theory, Ann Arbor: University of Michigan Press.

Galbraith, John Kenneth (1967), The New Industrial State, Boston: Houghton-Mifflin.

Geanakoplos, John (1987), ‘Arrow-Debreu Model of General Equilibrium,' in J. Eatwell, M. Milgate, and P. Newman (eds), The New Palgrave: A Dictionary of Economics, vol. 1., New York: Stockton, pp. 116-23.

Gobbin, Niko, Glenn Rayp and Dirk Van de Gaer (2007), 'Inequality and Growth: From Micro Theory to Macro Empirics,' Scottish Journal of Economics, 54 (September), 508-30.

Hale, Robert (1926), 'Labor Legislation as an Enlargement of Individual Liberty,' American Labor Legislation Review, 15, 155-60.

Hall, Robert and Charles Jones (1999), 'Why Do Some Countries Produce So Much More Output Per Worker Than Others?' Quarterly Journal of Economics, 114 (1), 83116.

Hepple, Bob (1996), 'The Future of Labour Law,' Comparative Labor Law \& Policy Review, 17 (4), 626-47. 
Hirsch, Barry (2007), 'What Do Unions Do for Economic Performance?' in J. Bennett and B. Kaufman (eds), What Do Unions Do? A Twenty Year Perspective, New Brunswick: Transaction Press, pp. 193-237.

Hirsch, Barry and John Addison (1986), The Economic Analysis of Unions: New Approaches and Evidence, Boston: Allen \& Unwin.

Hovenkamp, Herbert (1990), 'The First Great Law and Economics Movement,' Stanford Law Review, 42 (April), 993-1058.

Ippolito, Richard (2003), 'The Impact of the Minimum Wage if Workers Can Adjust Effort,' Journal of Law and Economics, 46, 207-27.

Jolls, Christine (2006), 'Law and the Labor Market,' Annual Review of Law \& Social Science, 2, 359-85.

Kates, Steven (1998), Say's Law and the Keynesian Revolution, Northampton: Elgar.

Kaufman, Bruce (1989), 'Labor's Inequality of Bargaining Power: Changes Over Time and Implications for Public Policy,' Journal of Labor Research, 10 (Summer), 285-98.

Kaufman, Bruce (1996), 'Why the Wagner Act? Reestablishing Contact with Its Original Purpose,' in D. Lewin, B. Kaufman, and D. Sockell (eds), Advances in Industrial and Labor Relations, vol. 7, Greenwich, CT: JAI Press, pp. 15-68.

Kaufman, Bruce (1997), 'Labor Markets and Employment Regulation: The View of the 'Old Institutionalists'.' In B. Kaufman (ed.), Government Regulation of the Employment Relationship, Madison: Industrial Relations Research Association, pp. $11-55$.

Kaufman, Bruce (1999a), 'Expanding the Behavioral Foundations of Labor Economics,' Industrial and Labor Relations Review, 52 (April), 361-92. 
Kaufman, Bruce (1999b), 'Emotional Arousal as a Source of Bounded Rationality,' Journal of Economic Behavior and Organization, 38 (February), 135-44.

Kaufman, Bruce (2003a), 'The Organization of Economic Activity: Insights from the Institutional Theory of John R. Commons,' Journal of Economic Behavior and Organization, 52 (1), 71-96.

Kaufman, Bruce (2004a), The Global Evolution of Industrial Relations: Events, Ideas and the IIRA, Geneva: International Labor Organization.

Kaufman, Bruce (2004b), 'The Institutional and Neoclassical Schools in Labor Economics,' in D. Champlin and J. Knoedler (eds), The Institutionalist Tradition in Labor Economics, Armonk: M.E. Sharpe, pp. 13-38.

Kaufman, Bruce (2005), 'The Social Welfare Objectives and Ethical Principles of Industrial Relations,' in J. Budd and J. Scoville (eds), The Ethics of Human Resources and Industrial Relations, Champaign: Labour and Employment Relations Association, pp. 23-59.

Kaufman, Bruce (2007a), 'What Unions Do: Insights from Economic Theory,' in J. Bennett and B. Kaufman (eds), What Do Unions Do?: A Twenty Year Perspective, New Brunswick: Transaction Press, pp. 12-45.

Kaufman, Bruce (2007b), 'Historical Insights: The Early Institutionalists on Trade Unionism and Labor Policy,' in J. Bennett and B. Kaufman (eds), What Do Unions Do?: A Twenty Year Perspective, New Brunswick: Transaction Press, pp. 46-78.

Kaufman, Bruce (2007c), 'The Institutional Economics of John R. Commons: Complement and Substitute for Neoclassical Economic Theory," Socio Economic Review, 5 (1), 3-46. 
Kaufman, Bruce (2007d), 'The Impossibility of a Perfectly Competitive Labor Market,' Cambridge Journal of Economics, 31 (5), 775-88.

Kaufman, Bruce (2008a), 'Chicago and the Development of Twentieth Century Labor Economics,' in R. Emmett (ed.), The Elgar Companion to the Chicago School of Economics, Aldershot, VT: Edgar Elgar, forthcoming.

Kaufman, Bruce (2008b), 'The Non-Existence of the Labor Demand/Supply Diagram, and Other Theorems of Institutional Economics,' Journal of Labor Research, 29 (Spring), forthcoming.

Kennedy, Duncan (1982), 'Distributive and Paternalist Motives in Contract and Tort Law, with Special Reference to Compulsory Terms and Unequal Bargaining Power,' Maryland Law Review, 41 (4), 563-658.

Keynes, John M. (1936), The General Theory of Employment, Interest, and Money, New York: Harcourt Brace.

Killingsworth, Mark (1983), Labor Supply, Cambridge: Cambridge University Press.

Kitson, M., R. Martin and F. Wilkinson (2000), 'Labor Markets, Social Justice, and Economic Efficiency,' Cambridge Journal of Economics, 24 (6), 631-41.

Klare, Karl (2000), “'Countervailing Workers’ Power as a Regulatory Strategy,' in Hugh Collins, Paul Davies and Roger Rideout (eds), Legal Regulation of the Employment Relationship, London: Kluwer Law International, pp. 63-82.

Kniesner, Thomas and Arthur Goldsmith (1987), 'A Survey of Alternative Models of Aggregate US Labour Market,' Journal of Economic Literature, 25 (September), 1241-80. 
Koedijk, Kees and Jeroen Kremers (1996), 'Deregulation: A Political Economy Analysis,' Economic Policy, 12 (October), 445-67.

Koot, Gerard (1987), English Historical Economics, 1870-1926, Cambridge: Cambridge University Press.

Lazear, Edward (2000), 'Economic Imperialism,' Quarterly Journal of Economics, 115 (February), 99-145.

Lester, Richard (1941), Economics of Labor, New York: Macmillan.

Letier, Brian (2003), 'American Legal Realism,' in W. Edmundson and M. Golding (eds), The Blackwell Guide to Philosophy of Law and Legal Theory, Oxford: Blackwell Publishing.

Linder, Marc (1989), The Employment Relationship in Anglo-American Law: An Historical Perspective, New York: Greenwood.

Linder, Marc (1990), 'The Minimum Wage as Industrial Policy: A Forgotten Role,' Journal of Legislation 16 (2), 151-71.

Mackaay, Ejan (2000), 'History of Law and Economics,' in B. Bouckaert and G. De Geest, eds., Encyclopedia of Law and Economics, vol. 1, pp. 65-117.

McCurdy, Charles (1984), “'The Roots of 'Liberty of Contract' Reconsidered: Major Premises in the Law of Employment, 1867-1937,' Yearbook 1984, Washington, D.C.: Supreme Court Historical Society.

Manning, Alan (2003), Monopsony in Motion, Princeton: Princeton University Press.

McIntyre, Richard and Yngve Ramstad (2002), 'John R. Commons and the Problem of International Labor Rights,' Journal of Economic Issues 36 (2), 293-301. 
Medema, Steve (1996), 'Ronald Coase and American Institutionalism,' in Research in the History of Economic Thought and Methodology, Greenwich: JAI Press, pp. 51-92.

Micheli, Thomas (2004), The Economic Approach to Law, $2^{\text {nd }}$ ed., Stanford: Stanford University Press.

Millis, Harry (1935), 'The Union in Industry: Some Observations on the Theory of Collective Bargaining,' American Economic Review, 25 (March), 1-13.

Milgrom, John and Paul Roberts (1992), Economics, Organization \& Management, Englewood-Cliffs, NJ: Prentice-Hall.

Miller, Gary (1991), Managerial Dilemmas, Cambridge: Cambridge University Press. Mincer, Jacob (1976), 'Unemployment Effects of Minimum Wage Changes,' Journal of Political Economy, 84 (August), S87-S104.

Mitchell, Daniel J.B. (1986), 'Inflation, Unemployment, and the Wagner Act: A Critical Reappraisal,' Stanford Law Review 38, (April), 1065-95.

Moss, David (1996), Socializing Security: Progressive Era Economists and the Origins of American Social Policy, Cambridge: Harvard University Press.

Oppenheimer, Margaret and Nicholas Mercuro (2005), Law and Economics: Alternative Economic Approaches to Legal and Regulatory Issues, Armonk: M.E. Sharpe.

Pearson, Heath (1997), Origins of Law and Economics, Cambridge: Cambridge University Press.

Perlman, Richard (1969), Labor Theory, New York: Wiley.

Perlman, Selig (1928), A Theory of the Labor Movement, New York: Macmillan. Polanyi, Karl (1944), The Great Transformation: The Political and Economic Origins of Our Times, Boston: Beacon. 
Posner, Richard (1984), 'Some Economics of Labor Law,' University of Chicago Law Review, 51 (4), 988-1011.

Posner, Richard (2007), Economic Analysis of Law, $7^{\text {th }}$ ed., Austin: Wolters Kluwer.

Prasch, Robert (1995), ‘Toward a ‘General Theory’ of Market Exchange,' Journal of Economic Issues, 29 (3), 807-28.

Prasch, Robert (1998), 'American Economists and Minimum Wage Legislation During the Progressive Era: 1912-1923,' Journal of the History of Economic Thought, 20 (2), 161-75.

Prasch, Robert (2000), 'Reassessing the Labor Supply Curve,' Journal of Economic Issues, 34 (3), 679-92.

Prasch, Robert (2004), 'How is Labor Distinct from Broccoli? Some Unique Characteristics of Labor and Their Importance for Economic Analysis and Policy,' in D. Champlin and J. Knoedler (eds), The Institutionalist Tradition in Labor Economics, Armonk: M.E. Sharpe, pp. 146-58.

Prasch, Robert (2005), 'The Social Cost of Labor,' Journal of Economic Issues, 39 (2), 1-7. Prasad, Monica (2006), The Politics of Free Markets, Chicago: University of Chicago Press.

Rader, Benjamin (1966), The Academic Mind and Reform: The Influence of Richard T. Ely in American Life, Lexington: University of Kentucky Press.

Reder, Melvin (1982), 'Chicago Economics: Permanence and Change,' Journal of Economic Literature, 20 (March), 1-38.

Reynolds, Morgan (1991), 'The Myth of Labor's Inequality of Bargaining Power,' Journal of Labor Research, 12 (2), 167-84. 
Rodgers, Daniel (1998), Atlantic Crossings: Social Politics in a Progressive Era, Cambridge: Harvard University Press.

Rottenberg, Simon (1981), The Economics of Legal Minimum Wages, Washington: American Enterprise Institute.

Rubin, Paul (1983), Business Firms and the Common Law: The Evolution of Efficient Rules, New York: Praeger.

Rutherford, Malcolm (2001), 'Institutionalism Then and Now,' Journal of Economic Perspectives, 15 (Summer), 173-94.

Samuels, Warren and A. Allan Schmid (eds) (1981), Law and Economics: An Institutional Perspective, Boston: Kluwer-Nijhoff.

Samuels, Warren, Steven Medema and A. Allan Schmid (eds) (1997), The Economy as a Process of Valuation, Lyme, NH: Edward Elgar.

Schmid, A. Allan (2004), Conflict and Cooperation: Institutional and Behavioral Economics, Malden: Blackwell.

Schwab, Stewart (1997), 'The Law and Economics Approach to Workplace Regulation,' in B. Kaufman (ed.), Government Regulation of the Employment Relationship, Madison: Industrial Relations Research Association, pp. 91-123.

Scully, Gerald (1992), Constitutional Environments and Economic Growth, Princeton: Princeton University Press.

Sen, Amartya (1999), Commodities and Capabilities, New York: Oxford University Press. Simon, Herbert (1982), Models of Bounded Rationality, vol. 2., Cambridge: MIT Press. Slichter, Sumner (1931), Modern Economic Society, $2^{\text {nd }}$ ed., New York: Henry Holt. 
Smith, Adam (1776), An Inquiry into the Nature and Causes of the Wealth of Nations, 1937 reprint, New York: Modern Library.

Solow, Robert (1990), The Labor Market as a Social Institution, Cambridge: Blackwell.

Spector, Horacio (2006), 'Philosophical Foundation of Labor Law,' Florida State University Law Review, 33 (Summer), 1119-48.

Summers, Clyde (1979), 'Industrial Democracy: America’s Unfilled Promise,' Cleveland State Law Review, 28 (1), 29-49.

Stabile, Donald (1993a), Activist Unionism: The Institutional Economics of Solomon Barkin, Armonk: M.E. Sharpe.

Stabile, Donald (1993b), 'Accountants and the Price System: The Problem of Social Cost,' Journal of Economic Issues, 27 (1), 171-88.

Standing, Guy (2004), Promoting Income Security as a Right: Europe and North America, London: Anthem.

Stigler, George (1966), The Theory of Price, $3^{\text {rd }}$ ed., New York: Macmillan.

Stigler, George (1976), 'The Xistence of X-Efficiency,' American Economic Review, 66 (1), 213-16.

Stiglitz, Joseph (2000), 'Democratic Development as the Fruits of Labor,'Perspectives on Work, 4 (1), 31-38.

Summers, Clyde, Kenneth Dau-Schmidt and Alan Hyde (2007), Legal Rights and Interests in the Workplace, Durham: Carolina Academic Press.

Summers, Lawrence (1989), 'Some Simple Economics of Mandated Benefits,' American Economic Review, 79 (2), 177-83. 
Sunstein, Cass (2000), Behavioral Law \& Economics, New York: Cambridge University Press.

Sunstein, Cass (2004), The Second Bill of Rights: FDR's Unfinished Revolution and Why We Need It More Than Ever, New York: Basic Books.

Taylor, George and Frank Pierson (1957), New Concepts in Wage Determination, New York: McGraw-Hill.

Taylor, Curtis (1995), 'The Long Side of the Market and the Short End of the Stick: Bargaining Power and Price Formation in Buyers, Sellers' and Balanced Markets,' Quarterly Journal of Economics, 110 (3), 837-55.

Taylor, James (1977), 'Exploitation through Contrived Dependence,' Journal of Economic Issues, 11 (March), 51-59.

Trebilcock, Michael (1993), The Limits of Freedom of Contract, Cambridge: Harvard University Press.

Valticos, Nicolas (1969), 'Fifty Years of Standard Setting Activities by the International Labour Organization,' reprinted in International Labour Review, 135 (2), 393-413. Van Overtveldt, Johan (2007), The Chicago School, Chicago: Agate.

Varian, Hal (1999), Intermediate Microeconomics, $5^{\text {th }}$ ed., New York: Norton.

Webb, Sidney (1912), 'The Economic Theory of a Legal Minimum Wage,' Journal of Political Economy, 20 (10), 973-98.

Webb, Sidney and Beatrice Webb (1897), Industrial Democracy, London: Longmans, Green.

Wedderburn, Lord K.W. (1988), 'Labour Law: Autonomy from the Common Law?' Comparative Labor Law \& Policy Journal, 9 (2), 219-52. 
Weiler, Paul (1990), Governing the Workplace: The Future of Labor and Employment Law, Cambridge: Harvard University Press.

Yergin, Daniel and Joseph Stanislav (2002), Commanding Heights: The Battle for Control of the World Economy, New York: Free Press.

Yonay, Yuval (1998), The Struggle for the Soul of Economics: Institutional and

Neoclassical Economists in America Between the Wars, Princeton: Princeton University Press.

\footnotetext{
${ }^{\mathrm{i}}$ The same may apply to new labor force entrants.

ii See Summers 1989 and Addison and Hirsch 1997 for more information.

iii Note that a direct change in the wage rate, such as by a minimum wage law, causes a movement along the demand curve, a change in some other variable affecting employment, such as the cost of a mandate, causes a shift.

${ }^{\text {iv }}$ The same applies to trade unions.

${ }^{\mathrm{v}}$ Firms may still own a large capital stock but rent out portions to workers now-turned independent contractors.

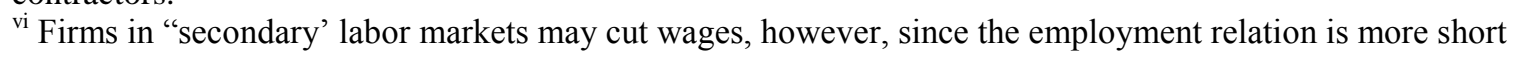
term and labor is more like a commodity.

${ }^{\text {vii }}$ Consider, for example, the research productivity of professors starting from 0 tenure protection to 100 percent.
} 